\title{
The 1oth International Congress of Byzantine Studies, Istanbul, September 15-21, 1955
}

\author{
Buket Kitapçı Bayrı*
}

\begin{abstract}
The aim of this paper is to better understand the significance of International Congresses of Byzantine Studies within the Byzantine studies in general and the 1oth International Congress of Byzantine Studies 1955-Istanbul, which has been overshadowed in memories by the most regretful events of 6-7 September, in particular. The paper briefly deals with the Byzantine studies and politics of culture in Turkey between 1926 and 1950s, which may have helped Istanbul's election as the host of 1oth International Congress. It focuses on the preparations for the 1oth International Congress by the Turkish organizing committee and Turkish government, based on the minutes of the Grand National Assembly of Turkey and the archival documents of Cahide Tamer, and finally it discusses the 1oth International Congress, members of the Turkish organizing committee, participants, papers, excursions, exhibitions, and publications.
\end{abstract}

Keywords: Byzantine studies, International Congresses of Byzantine Studies, 1oth International Congress of Byzantine Studies 1955-Istanbul, Byzantine monuments in Istanbul, politics of culture

\section{Milletlerarası Bizans Tetkikleri Kongresi, İstanbul, 15-21 Eylül 1955}

\section{Özet}

Bu yazının amacı 1924 ile 1955 yılları arasında gerçekleşen uluslararası Bizans çalışmaları kongrelerinin Bizans çalışmalarındaki yerini, özellikle şimdiye kadar başlı başına bir araştırmanın konusu olmamış ve hatıralarda 6-7 Eylül 1955 olaylarının gölgesinde kalmış 10. Milletlerarası Bizans Tetkikleri Kongresi'ni ve kongrenin Türkiye’deki Bizans çalışmalarına olan etkisini incelemektir. Makale 1926 ve 1950 yılları arasında Türkiye'deki kültür politikalarına ve Bizans çalışmalarına, ikincil kaynaklar ve şimdiye kadar fazla incelenmemiş ìstanbul Arkeoloji Müzeleri müdürü Aziz Ogan'ın arşivinden faydalanarak kısaca değinmektedir. Kongre hazırlıkları, organizasyon komitesi, kongre katılımcıları, sunulan tebliğler, kongre esnasında gerçekleşen geziler, sergiler ve katılımcılara sunulan yayınlar, Türkiye Büyük Millet Meclisi tutanakları, yakın zamanda araştırmacılara açılan restoratör-mimar Cahide Tamer arşivi, gazete haberleri, kongre tebliğ kitap ve yayınları ve ikincil kaynaklar yardımıyla tanıtılarak bu az bilinen kongreye ve zamanına 1şık tutulmaya çalışılmaktadır.

Anahtar kelimeler: Bizans çalışmaları, Uluslararası Bizans Çalışmaları Kongreleri, 1o. Milletlerarası Bizans Tetkikleri Kongresi 1955-İstanbul, İstanbul'daki Bizans yapılarının restorasyonu, kültür politikaları

Since the sixteenth century, collecting Greek manuscripts and the antiquarian hobby of collecting precious artefacts such as enamels or icons have been important stimuli in investigating Byzantine civilization. Travelers and learned men contributed to a developing interest in Byzantine studies between the sixteenth and eighteenth centuries. ${ }^{1}$ Although 
124 Byzantine studies suffered from negative vision diffused by the scholars of the Enlightenment such as Montesquieu, Voltaire, or Gibbon on this civilization, whose knowledge had been considered as inferior to the classical studies, significant steps towards creating the discipline came in the nineteenth century. In 1892 in Munich, Karl Krumbacher founded the Byzantinische Zeitschrift, the first journal to focus on this field. This was followed in 1894 in Russia by another journal specializing in Byzantine studies, Vizantijskij Vremennik, founded by Vasily Grigorievich Vasilievsky. Krumbacher set up an institute for Byzantine studies within the University of Munich in 1897. A few years later, in 1899, the first chair for Byzantine studies was created at the University of Sorbonne by Charles Diehl. ${ }^{2}$

The next most significant step for the discipline came with the institution of a series of international congresses of Byzantine studies, the first taking place in Bucharest in 1924 after being proposed by the Romanian scholar, Nicolae lorga. ${ }^{3}$ After this first congress and until World War II, four consecutive international congresses of Byzantine studies took place: the second in 1927 in Belgrade, the third in 1930 in Athens, the fourth in 1934 in Sofia, and the fifth in 1936 in Rome. During the fourth congress in Sofia, a permanent committee was formed, which would be responsible for organizing them.

This committee foreshadowed the creation of the AIEB (Association internationale des études byzantines), which would be founded in 1948. With the beginning of World War II, there was a rupture and it was only after the war in 1948 that the congress could be resumed. Between the years 1948 and 1953, four international congresses were organized. ${ }^{4}$ During the ninth congress held in Thessaloniki in 1953, Istanbul was chosen to be the venue of the tenth congress in 1955. After sixty-one years, in 2016 in Belgrade, Istanbul was elected for the second time to host the 24th International Congress of Byzantine Studies to be held in 2021 (ICBS 2021, Istanbul) by majority vote, against the candidacies of Munich and Nicosia.

The political and scholarly contexts in which the 1oth International Congress of Byzantine Studies was organized and the preparations for the congress and its contribution to Byzantine studies in Turkey are not well-known in modern scholarship. Apart from three reviews, no study has been conducted on the congress. ${ }^{5}$ Unfortunately, any memories of the congress have been overshadowed by the riots and plunder of September $6-7,1955 .^{6}$

The aim of this paper is thus to provide an introduction to better understand the 1oth International Congress of Byzantine Studies in the political and scholarly contexts as well as its contribution to Byzantine studies in Turkey. The selection of Istanbul/Constantinople,

1 Marie-France Auzépy and Jean-Pierre Grélois, Byzance retrouvée: érudits et voyageurs français (XVIe-XVIIle siècles), Chapelle de la Sorbonne, Paris 13 août-2 septembre 2001 (Paris: Centre d'études byzantines, néo-helléniques et sud-est européennes and Publications de la Sorbonne-Byzantina Sorbonensia, 2001).

2 On Byzantine Studies, see Elizabeth Jeffreys, John Haldon, and Robin Cormack, The Oxford Handbook of Byzantine Studies (Oxford: Oxford University Press, 2008), 3-20.

3 For modern studies on the first congresses, see Florina Fodac, "Le premier Congrès international des études byzantines (Bucarest, 14-20 avril 1924). Prémisses et context historique d'organisation," in Études byzantines et post-byzantines 5 (Bucarest: Academiei Române, 2006), 509-522; Marie Nystazopoulou-Pélékidou, "L'histoire des congrès internationaux des études byzantines - Première partie," Byzantina Symmeikta 18 (2008): 11-34; Sandrine Maufroy, "Les premiers congrès internationaux des études byzantines: entre nationalisme scientifique et construction internationale d'une discipline," Revue germanique internationale 12 (2010): 229-240; Tonia Kioussopoulou, "La délégation grecque au Ile Congrès international des études byzantines (Belgrade, 1927)," in Héritages de Byzance en Europe du Sud-Est à l'époque moderne et contemporaine, ed. Olivier Delouis, Anne Couderc, and Petre Guran (Athens: École française d'Athènes, 2013), 403411. For some selected testimonies on the first congresses, see Paul Graindor, "Le premier congrès des Études byzantines," Revue belge de philologie et d'histoire 3 (1924): 673-675; Henri Grégoire, "Notes et informations." Échos d'Orient 137 (January-March 1925): 56-67; Albert Vogt, "llle congrès international des études byzantines. Athènes 12-18 octobre 1930," Revue des questions historiques 51 (1931): 231-237; Henri Grégoire, "Le troisième congrès des études byzantines à Athènes (du 12 au 18 octobre 1930)," Byzantion 6 (1931): 509-516. For the proceedings of the first Byzantine Studies congresses, see Constantin Marinescu, ed., Compte-rendu du premier Congrès international des études byzantines. Bucarest, 1924 (Nendeln: Kraus Reprint, 1978 [1925]); Dragutin N. Anastasijević and Philaret Granić, eds., Deuxième congrès international des études byzantines. Belgrade, 1927. Sous le haut patronage de Sa Majestéle Roi des Serbes, Croates et Slovènes. Compterendu (Nendeln: Kraus Reprint, 1978 [1929]); Anastasios C. Orlandos, ed., Ille Congrès international des Études byzantines. Athènes 1930. Compte rendu (Nendeln: Kraus Reprint, 1978 [1932]); Bogdan D. Filov, ed., Actes du congrès international des études byzantines, Sofia, septembre 1934, 2 vols. (Sofia: Imprimerie de la Cour, 1935).

4 Venance Grumel, "Le IXe Congrès international des études byzantines (Thessalonique 12-15 avril 1953)," Revue des études byzantines 12 (1954): 214-217. On the ninth international congress, also see A.H. Megaw, "Ninth International Congress of Byzantine Studies," Archaeology 6, no. 3 (September 1953): 181-183.

5 Henri Grégoire, "Note provisioire sur le Xe congrès international d'études byzantines (lstanbul, 15-21 septembre 1955)," Byzantion 24, no. 1 (1954): 313-315; Raymond Janin, "Le Xe congrès international d'études byzantines (Istanbul, 15-21 septembre 1955)," Revue des études byzantines 13 (1955): 281-284; Romilly J.H. Jenkins, "Tenth International Congress of Byzantine Studies," Archaeology 9, no. 1 (March 1956): 6o-62.

6 Dilek Güven, "Riots against the Non-Muslims of Turkey: 6/7 September 1955 in the Context of Demographic Engineering," European Journal of Turkish Studies. Social Sciences on Contemporary Turkey 12 (2011), accessed November 22, 2019, https://journals.openedition.org/ ejts/4538. 
the city which served as the capital of the Byzantine Empire for nearly one thousand years, may seem a natural choice for the venue of this congress. However, apart from the location itself, scientific as well as political developments within the chosen country also played a role in the selection of the venues for the international congresses. Although conferences and symposiums as well as various articles and collected volumes have brought attention to the development of Byzantine studies in Turkey, the field remains wide open to further studies. ${ }^{7}$ This paper briefly summarizes the scientific developments in the Turkish Republic within the political and ideological contexts of the years from 1926 to the 1950 in the light of some selected secondary literature as well as references to the archives of Aziz Ogan, founder of the Izmir Archaeology Museum and later director of the Museums of Antiquities of Istanbul between 1931 and 1953, which are now accessible at Boğaziçi University. The paper then examines the political situation prior to the selection of Istanbul as the venue of the tenth congress. The minutes of the Grand National Assembly of Turkey, the archival documents of Cahide Tamer, ${ }^{8}$ the restoration architect of the Ministry of Education, Antiquities and Museums Directorate (1943-1956), provide a new glimpse into the preparatory stages of the congress. Finally, the background and personality of the members of the Turkish organizing committee, the participants of the congress, and the papers, excursions, exhibitions, and publications, all of which hint at the perceptions and attitudes of Turkish scholars and the government towards Byzantine heritage in Turkey in the 1950s, are discussed in the third section of the paper.

\section{Politics of Culture and Byzantine Studies in Turkey}

The first congresses of Byzantine studies were organized in countries rich with Byzantine heritage, such as Greater Romania, Greece, State of Slovenes, Croats and Serbs, ${ }^{9}$ and Bulgaria, which had recently constructed their nation-states and were resurging from the dismantled Ottoman Empire before or following World War I. As large interdisciplinary and international events, these congresses were also political statements for these host countries. ${ }^{10}$ Receptions, spectacles, and excursions in the hosting city and country were considered as privileged occasions to "show off" the diverse aspects of the territories, picturesque landscapes, and "westernized promptness and exactness of the Balkan nations." congress, Nicolae lorga, most of whose work aimed to put Romania in its rightful place in world history, argued that the first international congress in Bucharest promoted the international recognition of the Romanian nation. According to Maria NystazopoulouPelekidou, lorga considered Southeastern European culture as the prolongation of Byzantine traditions. ${ }^{12}$

\footnotetext{
7 For some selected major works on Byzantine studies in Turkey, see Semavi Eyice, "Türkiye'de Bizans Sanatı Araştırmaları ve İstanbul Üniversitesi'nde Bizans Sanatı," in Cumhuriyet'in 5o. Yllına Armağan (lstanbul: İstanbul Üniversitesi Edebiyat Fakültesi Yayınları, 1973), 375-428; "Türkiye'de Bizans Mimarisi Hakkında Yabancı Araştırmaların Kısa Tarihçesi (ikinci Dünya Savaşına Kadar)," Sanat Tarihi Yıllığı (Istanbul: İstanbul Üniversitesi Edebiyat Fakültesi Yayınları, 1976), 453-469; Nevra Necipoğlu, "Türkiye'de Bizans Tarihçiliğinin Dünü, Bugünü ve Sorunlar1," Toplumsal Tarih 112 (2003): 72-77; Melek Delilbaş1, "The Classical Tradition, Byzantine and Modern Greek Studies in Turkey and Future Prospects," Association internationale d'études du Sud-Est Européen Revue 35-39 (2005-2009): 259-266; Engin Akyürek, "Modern Türkiye'de Bizans Sanatı Tarihi," Cumhuriyet Dönemi Geçmişe Bakış Açılart: Klasik ve Bizans Dönemleri, ed. Scott Redford and Nina Ergin (Istanbul: Koç Üniversitesi Yayınları, 2010), 241-262; Şule Kılıç Yıldız, "A Review of Byzantine Studies and Architectural History in Turkey Today," Middle Eastern Technical University Journal of the Faculty of Architecture 28, no. 2 (2011): 63-80. On perceptions of the past, especially of classical heritage and archaeology in Turkey, see Tuğba Tanyeri-Erdemir, "Archaeology as a Source of National Pride in the Early Years of the Turkish Republic," Journal of Field Archaeology 31, no. 4 (2006): 382-384; Scott Redford and Nina Ergin, eds., Perceptions of the Past in the Turkish Republic: Classical Periods (Leuven: Peeters, 2010). This volume is also published in Turkish, see above Cumhuriyet Dönemi Geçmişe Bakış Açıları. I would like to thank Prof. Dr. Melek Delilbaşı for providing me an offprint of her paper. On a recent symposium organized by the Istanbul Research Institute, "Discovering Byzantium in Istanbul: Scholars, Institutions, and Challenges (1800-1955), 16-18 November 2017," relating to Byzantine studies in Istanbul until 1955, see https://en.iae.org.tr/Images/pdf/etkinlikler/ sempozyum/istanbuldabizansikesfetmek.pdf. The proceedings of the symposium will be published in 2020 .

8 Although several monographs have been written on Cahide Tamer and her involvement in the architectural repairs of the Byzantine monuments in Istanbul, the archives of Cahide Tamer, which were donated to Koç University, have not been studied. The archives were very recently introduced to the scholarship in a talk by Barıs Altan and Zeynep Ahunbay ("ANAMED Library Talks," Research Center for Anatolian Civilizations, Istanbul, May 7, 2019). This paper provides some photos and information from Cahide Tamer's archives relevant to the repairs of Byzantine monuments prior to the congress. On Cahide Tamer and her restorations, see Cahide Tamer, İstanbul Bizans anttlar ve onarımları (İstanbul: Türkiye Turing ve Otomobil Kurumu, 2003); Başar Başarır, "30 Yıl Restorasyon: Cahide Tamer," istanbul 13 (1995): 97-98.

9 State of Slovenes, Croats and Serbs, which is also called Kingdom of Slovenes, Croats and Serbs, was a short-lived state, which existed between 1918 and 1929. In 1929, it was renamed as the Kingdom of Yugoslavia.

10 Mayfourt, "Les premiers congrès internationaux des études byzantines," 239-240.

11 lbid., 237.

12 Ibid. Nystazopoulou-Pélékidou, "L'histoire des congrès internationaux des études byzantines," 16-17. Also see Marinescu, Compterendu du premier congrès international des études Byzantines, 4-5. 1 would like to thank Prof. Athanasios Markopoulos, general secretary of AIEB, for having drawn my attention to the articles of Mayfourt and Nystazopoulou-Pélékidou and kindly sharing them with me. On
} 
Byzantine scholars repeatedly pointed out that the Balkan nations were the living examples of Byzantine culture in modern days. The Belgian historian Henri Grégoire emphasized that Byzantine studies carried a very important political and national sensitivity for the peoples of Southeastern Europe. He argued that from an historical perspective, the Balkan Wars and World War I were fought by the peoples of Southeastern Europe in order to preserve their Byzantine traditions. According to Grégoire, emerging victorious from these fights, these people were now able to embrace their glorious Byzantine heritage more fervently. ${ }^{13}$ Another Byzantinist, Venance Grumel noted that the congresses, which took place in Greece first in 1930 in Athens and then in 1953 in Thessaloniki, were national events for Greeks. According to Grumel, the Greek nation was so proud of its religious traditions that the congresses were inaugurated with solemn Byzantine masses. ${ }^{14}$

The first international congresses were presented as a hope for a Pan-European union, serving as a mediator to bring together a dismantled Europe of the postwar period. ${ }^{15}$ Apart from the political aspect, some of the organizers also thought that the congresses had an important role in bringing the Western and Eastern Christian churches together. During the congress in Belgrade, the Catholic clergy officially participated. The Orthodox patriarchs of Constantinople, Jerusalem, and Alexandria as well as the Church of Cyprus officially attended the third congress in Athens. During the 1930 congress in Athens, Konstantinos Amantos proposed that a committee should be founded in order to research and study the documents related to the situation of the Christian communities under Turkish domination between the eleventh and nineteenth centuries. ${ }^{16}$

The Balkan Wars and World War I, which were considered by some Byzantinists of the postwar period as "struggles for Balkan nations to preserve their Byzantine traditions, ${ }^{, 17}$ were fought against the Ottoman Empire, the predecessor of the Turkish Republic, which still held central parts of the former Byzantine Empire, Anatolia, Thrace, and most importantly, Constantinople. The Ottomans were late to embrace a national identity compared to the nascent Balkan nations. As for the Ottomans, the ideological inclinations of Abdülhamid II (1876-1909) to Pan-Islamism and the disastrous defeats during the Libyan (1911-1912) and Balkan Wars (1912-1913) resulted in the rise of Turkish/Islamic nationalism in the Ottoman Empire. This national cultural self-definition would continue into the Turkish Republic until 1926. The Turkish republican regime took a turn in 1926, however. Although it retained the Turkish dimension of nationalism, it moved away from Islam and embraced an outwardly secularist ideology as proof to its commitment to modernity, desiring to break away from the image of the disastrous years of the late Ottoman Empire.

History and archaeology played an important role in the creation of nation-states. The $1930 \mathrm{~s}$ witnessed a radical process of rewriting history to position the Turkish nation at the center of civilizations. It was largely an attempt of the new Turkish nation-state to create a rich, ancient, and historically legitimate origin of the nation. The Turkish History Thesis embraced the earlier civilizations of Anatolia, breaking off with the more recent Ottoman and Islamic past. The desire was to marginalize the country's Islamic heritage, but according to Edhem Eldem, it was also a reaction to the dominant paradigm of Western history, which perceived Greek, Roman, and Judeo-Christian heritage as the exclusive cradle of Western civilization. What was left to the Turks were the remaining ones: Hittites, Sumerians, and Etruscans. It did not matter whether the West believed in this construction or not. The theories were for internal audiences, aiming to show that modern Turkey was no longer willing to accept a

the conception of permanence of Byzantine forms and the Byzantine cultural heritage in the post-Byzantine period, see Nicolae Iorga, Byzance après Byzance: Continuation de l'histoire de la vie byzantine (Bucarest: Institut d'études byzantines, 1935).

13 Nystazopoulou-Pélékidou, "L'histoire des congrès internationaux des études byzantines," 17-18.

14 Grumel, "Le IXe Congrès international des études byzantines," 214-215.

15 During the third congress, Albert Vogt stated, "Si le congrès d'Athènes fut un congrès scientifique, il fut autre chose aussi. Ce fut un congrès de la paix, un grand acte officiel de bonne volonté réciproque, et, pourquoi ne pas ajouter, un premier espoir d'union paneuropéenne [...] On eut, à certains moments, comme la sensation que Byzance revivait et attirait de nouveau dans son rayonnement, d'abord les peuples du Sud-Est européen qui se réclament d'elle comme de leur mère commune, mais ensuite aussi les descendants de ceux qui, en 1204 prirent Constantinople et détruisirent l'Empire 'gardé de Dieu." Vogt, "Ille congrès international des études byzantines," 232. 16 Nystazopoulou-Pélékidou, "L'histoire des congrès internationaux des études byzantines," 25-26. 17 lbid, 17 . 
This shift in the politics of culture had a powerful impact on history writing, archaeology, and museology as well as on the development of different chairs in the newly opened universities, and this surprisingly did not harm the perception and treatment of the classical heritage. Greek and Roman ruins and sites were thus kept within the framework of the country's cultural heritage. As Eldem shows, "Turkish nationalism remained flexible enough to maintain a balance between its Westernist and xenophobic tendencies; cultivating the same admiration as the West for classical wonders of Anatolia." ${ }^{19}$ The regime wished to present to the world an image of the country as a land of history and a bridge between civilizations.

Byzantine studies within this context attracted the attention of a few Turkish scholars such as Arif Müfid Mansel, Aziz Ogan, Rüstem Duyuran, Nezih Firatlı, and Necati Dolunay, who engaged in archaeological excavations and surveys of Byzantine sites and monuments. ${ }^{20}$ More strikingly, many foreign Byzantine archaeologists, art historians, and historians were invited or simply came to Turkey on their own during this period. They conducted archaeological excavations and research and taught at Turkish universities. Thomas Whittemore, the American philanthropist and founder of the Byzantine Institute of America, worked in the study to preserve the mosaics of Ayasofya Mosque (Hagia Sophia Church) in Istanbul in 1931 and later in the restoration of Kariye Mosque (Chora Church). ${ }^{21}$ He played a crucial role in the conversion of Ayasofya Mosque into a museum in 1934. David Talbot Rice, a British art historian and archaeologist, excavated the Great Palace, worked in the Bodrum Mosque (Myrelaion Church) in Istanbul, and conducted surveys around Trebizond. ${ }^{22}$ Alfons M. Schneider was active in Istanbul as well as in İznik (Nicaea). ${ }^{23}$

Most of these works, surveys, and excavations can be traced in the Aziz Ogan Archives, ${ }^{24}$ which reflect quite an active scientific environment during which, in collaboration with foreign archaeologists and research institutes, many excavations and surveys were carried out in Istanbul and its vicinities. Aziz Ogan's letters to Byzantinists such as Thomas Whittemore, Alfons Maria Schneider, James Houston Baxter, and David Russell from St. Andrews University, George P. Oikonomos from the Academy of Athens, and to the editors of journals such as Byzantion and Le Muséon, give witness to the lively and cordial relations between the Byzantine scholars and the director of the Museums of Antiquities in Istanbul. ${ }^{25}$

The rich collection of letters and various documents in the Aziz Ogan Archives, which are held at Boğaziçi University, offers a rich insight into the perception of archaeology as the pride of the newly founded Turkish nation-state. ${ }^{26}$ The information on the new finds was shared with the members of the parliament, the mayor of Istanbul, and other politicians. Archaeology was not only considered a scientific inquiry but an extremely significant ideological and political subject. One should note that Aziz Ogan himself was a member of the founding political party of the Turkish Republic, the Republican People's Party (Cumhuriyet Halk Partisi, CHP). Ogan was a colleague and friend of Mehmed Fuad Köprülü, an eminent scholar, who was also a CHP member. Köprülü would break from the CHP in 1946 and become one of the founders of the Democrat Party (DP).

\footnotetext{
18 Edhem Eldem, "Cultural Heritage in Turkey: An Eminently Political Matter," Essays on Tourism, Heritage and Society in the Mena Region. Proceedings of the International Heritage Conference 2013 at Tangier, Morocco, ed. Dieter Haller, Achim Lichtenberger, and Meike Meerpohl (Paderborn: Ferdinand Schöningh, 2015), 67-92, especially 82. 19 lbid., 83 .

20 For studies in Byzantine archaeology and architecture in Turkey, see Yıldız, "A Review of Byzantine Studies."

21 See Kariye. From Theodore Metochites to Thomas Whittemore: One Monument, Two Monumental Personalities, ed. Holger A. Klein, Robert G. Ousterhout, Brigitte Pitarakis (Istanbul: Pera Museum, 2010).

22 For a firsthand witness of David Talbot Rice's surveys and works in Turkey, see Tamara Talbot Rice and Elizabeth Talbot Rice, Tamara: Memoirs of St. Petersburg, Oxford and Byzantium (London: Murray, 1996).

23 For a selected bibliography, see Semavi Eyice, "Alfons Maria Schneider," TDV Islâm Ansiklopedisi, accessed November 12, 2019, https:// islamansiklopedisi.org.tr/schneider-alfons-maria.

24 On Aziz Ogan, see Semavi Eyice, “Ölümü Münasebetiyle: İstanbul Arkeoloji Müzeleri eski müdürü Aziz Ogan (1888-1956)," Türk Yurdu 263 (December 1956): 421-428; Selvihan Kurt, "Aziz Ogan ve Yabancı Bizantologların Yazışmaları lşı̆̆ında İstanbul'da Bizans Mirası Tartıșmaları," Toplumsal Tarih 308 (2019): 62-69.

25 For Aziz Ogan archives, see http://digitalarchive.boun.edu.tr.

26 Tanyeri-Erdemir, "Archaeology as a Source of National Pride in the Early Years of the Turkish Republic."
} 
128 Mehmed Fuad Köprülü penned a lengthy article in 1931 on the impact of Byzantine institutions on Ottoman institutions, ${ }^{27}$ which can be considered a reaction against the ideas of "orientalist" Byzantinists, such as Diehl and Gibbons, who related the emergence of the Ottoman Empire and its state-building to borrowings from Byzantine-Roman institutions. Köprülü, who had worked and published on Byzantine institutions as early as 1931, seems to have played an important role in the selection of Istanbul as the venue for the tenth congress when he was the minister of foreign affairs in 1953.

The period between 1926 and 1950 was incredibly active in terms of translations of Greek and Roman classical texts into Turkish. Some secondary literature on Byzantine history, such as Charles Diehl's Histoire de l'Empire byzantin and Alexander A. Vasiliev's The Byzantine Empire I, were also translated into Turkish. ${ }^{28}$ There were original works by Akdes Nimet Kurat (1933), Reşad Ekrem Koçu (1934), and Şerif Baştav (1947) devoted to Byzantine history. ${ }^{29}$ In terms of higher education, the Faculty of Letters was established as the core of Ankara University in 1935. Courses on history, geography, anthropology, as well as departments on classical and modern languages such as Greek, Latin, Hungarian, Persian, Arabic, Hindi, Chinese, and Russian were inaugurated.

During World War Il, scientists escaping from Nazi Germany established chairs at Ankara University: Georg Rohde in classical philology, Benno Landsberger in Sumerology, and László Rásonyi in Hungarology. Under Rodhe’s guidance, many future Turkish classicists were educated, including Azra Erhat, Samim Sinanoğlu, and Suat Sinanoğlu. At Istanbul University, a classical department was established in 1943-1944. Its first instructors were Ronald Syme and George Ewart Bean. Zeki Perek, Muzaffer Taşlıklığlu, and Müzehher Erim were educated under their guidance. Between the years 1941 and 1944, Steven Runciman gave lectures on Byzantine art and history at Istanbul University. After Runciman, Ernst Diez taught Byzantine art between 1945 and 1949, followed by Philipp Schweinfurth between 1950 and 1954. From 1956 onwards, Byzantine art history lectures were given by Semavi Eyice, who would later establish the chair of Byzantine art at Istanbul University in 1963.

Few scholars from Turkey attended the first international congresses of Byzantine studies. One Turkish observer attended the fourth congress in Sofia in 1934, and two Turkish scholars attended the fifth congress in Rome in 1936. The first Turkish scholar to present a paper at the congress was Muzaffer Ramazanoğlu, then director of the Ayasofya Museum in Istanbul, at the eighth congress in Palermo in $1951 .{ }^{30}$ During the ninth congress in Thessaloniki in 1953, scholars from Turkey presented six papers. ${ }^{31}$ It was during this congress that Istanbul was chosen as the venue for the tenth congress. The reviews on the congress in Thessaloniki do not mention the vote nor any reasons or discussions behind the selection of Istanbul. Şule Kılıç Yıldız mentions briefly in an article that the Turkish minister of foreign affairs (Mehmed Fuad Köprülü, 1950-1955) sent an invitation to the congress in Thessaloniki in order to promote and support the election of Istanbul as the next venue for the next congress. ${ }^{32}$

27 Mehmet Fuad Köprülü, "Bizans Müesseselerinin Osmanlı Müesseselerine Tesiri Hakkında Bazı Mülahazalar," Türk Hukuk ve Iktisat Tarihi Mecmuast 1 (1931): 165-313.

28 Charles Diehl, Bizans Imparatorluğu Tarihi, trans. Tevfik Bıyıklığlu (Istanbul: Vakit Matbaası, 1937). Tevfik Bıyıklığlu was the first director of Türk Tarihi Tetkik Cemiyeti / Türk Tarih Kurumu (Turkish History Foundation); Charles Diehl, Bizans Imparatorluğu Tarihi, trans. Cevdet R. Yularkıran (Istanbul: Kanaat Kitapevi, 1939); Alexander A. Vasiliev, Bizans Imparatorluğu Tarihi, Cilt 1, trans. Arif Müfid Mansel (Ankara: Maarif Vekaleti, 1943).

29 Akdes Nimet Kurat, Die türkische Prosopographie bei Laonikos Chalkokondyles (Hamburg: Neimann \& Moschinski, 1933); Reşat Ekrem Koçu, Bizans Tarihi (Şarki Roma Imparatorluğu) 395-1453 (Istanbul: Muallim Ahmet Halit Kitaphanesi, 1934); Şerif Baştav, Ordo Portae: description grecque de la Porte et de l'armée du sultan Mehmed II (Budapest: Pázmány Péter Tudományegyetemi Görög Filológiai Intézet, 1947).

30 Muzaffer Ramazanoğlu, "Neue Forschungen zur Architektur-Geschichte der Irenen-Kirsche und des Komplexes der Sophien-Kirche," Atti dello VIII Congresso Internazionale di Studi Bizantini: Palermo, 3-10 Aprile 1951, v. 2 (Roma, 1953), 232-235.

31 Mgr Gennadios Arabadjoglou, "Sur une lettre du patriarche de Cple Athanase Ir (sous Andronic I Ir)"; Paolo Verzone, "La moschea Cumanun di Adalia;" P. Demircioglu-Sideridis, "Welche Kirche ist die heutige Küdjük Aghia Sofia Moschee?"; Semavi Eyice, "Remarques sur deux anciennes églises byzantines d'Istanbul: Koca Mustafa Pasa camii et l'église du Yusat tepesi"; E. Mamboury "La Suisse, province de l'art byzantin;" and E. Mamboury, "Le forum de Constantin. La chapelle de saint Constantin et les mystères de la Colonne Brûlée (résultats des sondages opérés en 1929 et 1930)"; Henri Grégoire, "Le IXe congrès des études byzantines Thessalonique, $12-25$ avril 1953. Rapport préliminaire," Byzantion 22 (1952): 422.

32 According to Athanasios Markopoulos, the AIEB archives, which are cared for and handled by the secretary of the AlEB, contain information only on the post-1960s congresses, and hence the vote and reasons for lstanbul's election cannot be obtained from these archives. For Şule Kılıç Yıldız's reference, see Yıldız, "A Review of Byzantine Studies," 68. 
The political context in Turkey between 1950 and 1953 may have also helped the decision to select Istanbul as the venue of the tenth congress. Although the Ottoman past and Islam started to infiltrate into mainstream culture shortly after the death of Mustafa Kemal Atatürk in 1938 (and especially during the 1950s) and although the DP made efforts to promote Islam to gain political support against the CHP, the dominant ideology of the early Turkish Republic was not overthrown but competed and sometimes pragmatically overlapped with the re-introduction of Islam into the national identity. ${ }^{33}$ The DP not only promoted Islam to gain political support in the country but also led a pro-Western policy at the beginning of its rule. Turkey joined NATO in 1952. Upon Turkey's alliance with NATO, relations with Greece began to improve. King Paul and Queen Frederika visited Turkey in 1952. In the same year, Turkish President Celal Bayar visited Greece. In 1954, however, the relations with Greece began to deteriorate due to the Cyprus issue. ${ }^{34}$

The DP allowed non-Muslim Turkish citizens to integrate into the party. During the 1950 parliamentary elections, four non-Muslim candidates, Dr. Vasil Konos and Ahilya Moshos (from the Rum [Greek] community), Salamon Adato (from the Jewish community), and Andre Vahram (from the Armenian community), were elected to the Grand National Assembly as DP deputies. This trend continued in the 1954 elections, and this time Aleksander Hacopulos and Ahilya Moshos (from the Rum community), Henri Soryano (from the Jewish community), and Andre Vahram (from the Armenian community) were elected as DP deputies. In 1952, Turkish Prime Minister Adnan Menderes visited the patriarch of Constantinople, Athenagoras (19481972). This was a first in Turkish republican history. ${ }^{35}$ Along with the scholarly developments, the above-mentioned political developments were most probably warmly welcomed by some Byzantine scholars who had been voicing their interest in the situation of Christians living in the Ottoman Empire and Turkish Republic during the first congresses. It is plausible that all these developments subsequently had a positive effect on the consideration of Istanbul as the venue for the tenth congress.

\section{Preparations for the 1oth International Congress of Byzantine Studies}

With the proclamation of the republic, the status of Istanbul was ceded to Ankara, which became the capital of the republic and the symbol of the new regime. In the 1930s, historical monuments in Istanbul became deteriorated, dysfunctional, and surrounded by empty plots and shabby houses. In the 1950 s the Ottoman past as well as its 470-year-old capital Istanbul became central to the state's politics of culture and identity. ${ }^{36}$ In 1950, a few months before the victory of the DP in parliamentary elections, İsmet İnönü (president of the Turkish Republic) founded an association called 500. Yıl ve Müteakip Fetih Y1lları Kutlama Derneği (The Association for Celebrating the 5ooth and Subsequent Anniversaries of the Conquest of Constantinople). ${ }^{37}$ The president of the association was Aziz Ogan. One of the duties of the association was to oversee the restoration and protection of antiquities in Istanbul. After the DP's victory, a budget was allotted to the association for the restoration and protection of antiquities, including a statue of Mehmed II, and the preparations for the celebrations. Aydin Arakon made a film called İstanbul'un Fethi (Conquest of Istanbul) under the state's auspices. The celebrations started on May 29, 1953 by the city walls of Istanbul, and the patriarch of Constantinople, the Armenian patriarch, and the chief rabbi attended the celebrations. In order not to damage the fragile relations with Greece, Prime Minister Adnan Menderes and President Celal Bayar did not attend the celebrations, and Greek newspapers of the time highly appreciated that decision..$^{8}$

33 Eldem, "Cultural Heritage in Turkey: An Eminently Political Matter," 84.

34 See Güven, "Riots against the Non-Muslims of Turkey: 6/7 September 1955."

35 Ayhan Aktar, "6-7 Eylül 1955, Cumhuriyet Tarihinin En Karanlık Gecesi," accessed June 25, 2019, https://www.sosyalbilimler.org/ayhanaktar-yazdi-6-7-eylul-1955-cumhuriyet-tarihinin-en-karanlik-gecesi/.

36 Nur Altınyildız, "The Architectural Heritage of Istanbul and the Ideology of Preservation," Muqarnas 24 (2007): 281-305, see especially 295-305 for the 1950 .

37 The conquest of Constantinople was celebrated for the first time during the Ottoman Empire in 1914 by Ittihat ve Terakki Cemiyeti (Committee of Union and Progress).

38 Çă̆la Tagmat, "Fetih Derneği ve İstanbul'un Fethi'nin 50o. Y1l1," Tarih, Kültür ve Sanat Araştırmaları Dergisi 3, no. 4 (December 2014 ): 57. 
The selection of Istanbul as the venue for the tenth congress as well as the prospect of the arrival of many international scholars to Istanbul and of their travels within Turkey seem to have acted as a powerful impetus in the restoration and repair efforts of Byzantine monuments in Istanbul. The preparations for the congress started at the highest level of state, which can be traced in the minutes of the Grand National Assembly of Turkey. The minutes dating to November 30, 1954 refer to the congress and its organizing committee. It is stated that the success of the congress is a scientific honor for the Turkish nation, and hence the assembly decided to allot an important sum of budget for the restoration, maintenance, and cleaning of Byzantine and other historical monuments in Istanbul and around Turkey; in addition, a sum was allotted for the preparations of the congress itself. Among the monuments in Istanbul, Ayasofya Museum, Hagia Eirene, Fethiye Mosque (Pammakaristos Church), İmrahor Mosque (Stoudios Church), Fenari İsa Mosque (Lips Monastery), Bodrum Mosque, Kariye Mosque, Tekfur Palace, the city walls, Yedikule, Golden Gate, Rumeli Castle, and Topkapı Palace are mentioned as benefitting from these efforts. ${ }^{39}$

From the minutes of the Grand National Assembly dating to February 2, 1955, we learn that a discussion was held at the parliament about Abbasid, Umayyad, and Byzantine lead seals. Referring to a journal article on the disappearance of lead seals in the Archaeological Museums in Istanbul, the DP deputy of Malatya raised a question, and the minister of education gave a lengthy answer on the preservation and protection of lead seals in Turkish museums. ${ }^{40}$ At the beginning of 1955, during several gatherings at the Grand National Assembly, the DP deputy of Antalya, Burhanettin Onat, emphasized the necessity of restoring and cleaning the Byzantine monuments in Istanbul and the importance of the forthcoming congress. He complained about the ongoing dire situation of all historical monuments in Istanbul and urged all relevant institutions to take immediate action on this issue. ${ }^{41}$ All these discussions at the Grand National Assembly reflect the importance that the government attached to the congress.

The archives of Cahide Tamer ${ }^{42}$ offer testimony to the fact that the decisions, which had been made at the Grand National Assembly, were in fact implemented. In the archives, a survey notes the necessary repairs for each Byzantine monument in Istanbul. ${ }^{43}$ Tamer's archives also include detailed budgets on the restoration, cleaning, and small repairs of historical monuments in Istanbul. The Ayasofya Museum, the Kariye, Fethiye, İmrahor, Fenari İsa, and Bodrum mosques, and the Tekfur Palace were among the Byzantine monuments to be restored, while monuments such as the Column of Arcadius, the Anemas Dungeons, the Byzantine palaces on the Marmara coast, the Hippodrome and its surroundings, and the Bodrum Mosque were listed to be cleaned and repaired. ${ }^{44}$ Tamer documented the Kariye, Fethiye, İmrahor, Fenari İsa, and Bodrum mosques and the Tekfur Palace with photographs of the monuments before and after repairs and cleaning (fig. 1-17). ${ }^{45}$

39 For a detailed list of the areas to be maintained, cleaned and restored in Istanbul and Turkey, and the detailed budget allotted to this mission, see the minutes of the Turkish Grand National Assembly. TBMM, Devre: X, İctima: 1, S. Sayıs1: 183. "1955 yilı Muvazenei Umumiye kanunu lâyihası ve Bütçe Encümeni mazbatası" (November 30, 1954), accessed November 12, 2019, https://www.tbmm.gov.tr/tutanaklar/ TUTANAK/TBMM/d1o/c005/tbmm10005042ss0183.pdf, 237-241. According to Nur Altiny1ldiz, the interventions prior to the congress addressed appearances. Monuments that scholars would visit were hastily cleaned and patched up to avoid embarrassment. Altınyldız, "Architectural Heritage of Istanbul," 296. Although this aspect of rapid cleaning and hasty repairs are visible in the documents and the concerns of embarrassment were voiced by the politicians, the impetus for repair and restoration, which had started in preparation for the congress, continued well into the 1960 .

40 TBMM, Devre: X, İçtima: 1, İntikat: 35 (November 2, 1955), accessed November 12, 2019, https://www.tbmm.gov.tr/tutanaklar/ TUTANAK/TBMM/d1o/coo5/tbmm10005035.pdf, 10-11.

41 TBMM, Devre: X, İçtima: 1, İntikat: 35 (November 2, 1955), 1955, accessed November 12, 2019, https://www.tbmm.gov.tr/tutanaklar/ TUTANAK/TBMM/d1o/coo5/tbmm10o05045.pdf, 433; Devre: X, İçtima: 1, Cilt 5, İntikat: 48 (November 24, 1955), 1955, accessed November 12, 2019, https://www.tbmm.gov.tr/tutanaklar/TUTANAK/TBMM/d10/coo5/tbmm10005048.pdf, 638-639; Devre: X, içtima: 1, Cilt 5, Intikat: 52 (November 28, 1955), 1955, accessed November 12, 2019, https://www.tbmm.gov.tr/tutanaklar/TUTANAK/TBMM/d1o/ c0o5/tbmmiooo5052.pdf, $985-987$.

42 On Cahide Tamer, see https://www.arkeolojikhaber.com/haber-cahide-tamer-2106o

43 Cahide Tamer Collection, Koç University Suna Kıraç Library, CTA_S103_Do1_doc_16_03; CTA_S103_Do1_doc_16_04.

44 For the 1955 budget and lists of monuments to be restored in Istanbul, see Cahide Tamer Collection, Koç University Suna Kıraç Library, CTA_S103_Do1_doc_15; CTA_S103_Do1_doc_16_01; CTA_S103_Do1_doc_16_02; CTA_S103_Do1_doc_16_03; CTA_S103_Do1_ doc_16_04; CTA_S103_Do1_doc_16_05; CTA_S103_Do1_doc_16_06; S108_A01_doc_01.

45 Cahide Tamer Collection, Koç University Suna Kıraç Library, CTA_Sı8_Aor. 
Figure 1a-1b: Fethiye Mosque, before and after. Cahide Tamer Collection, Koç University Suna Kıraç Library, CTA_S108_Ao1_ phg_04 and CTA_S108_ A01_phg_05.

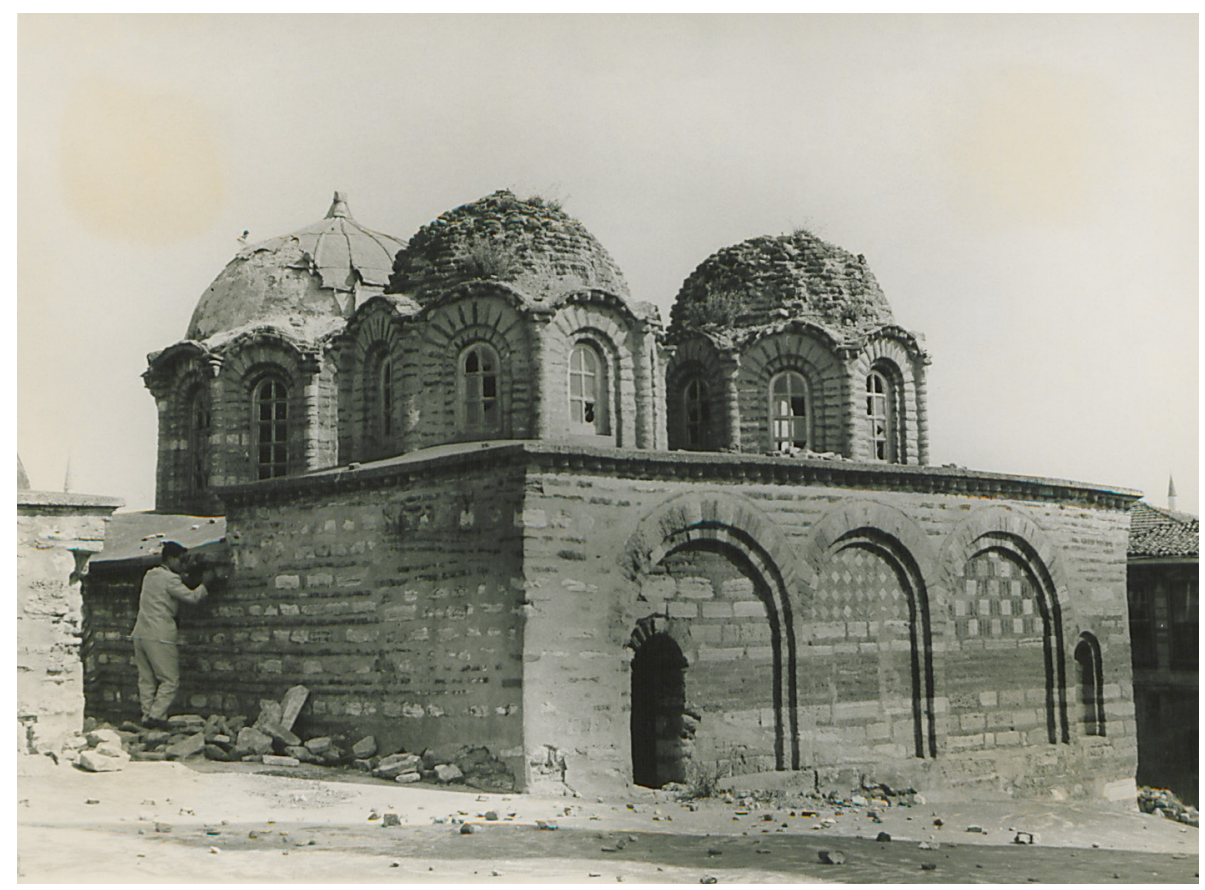

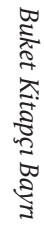

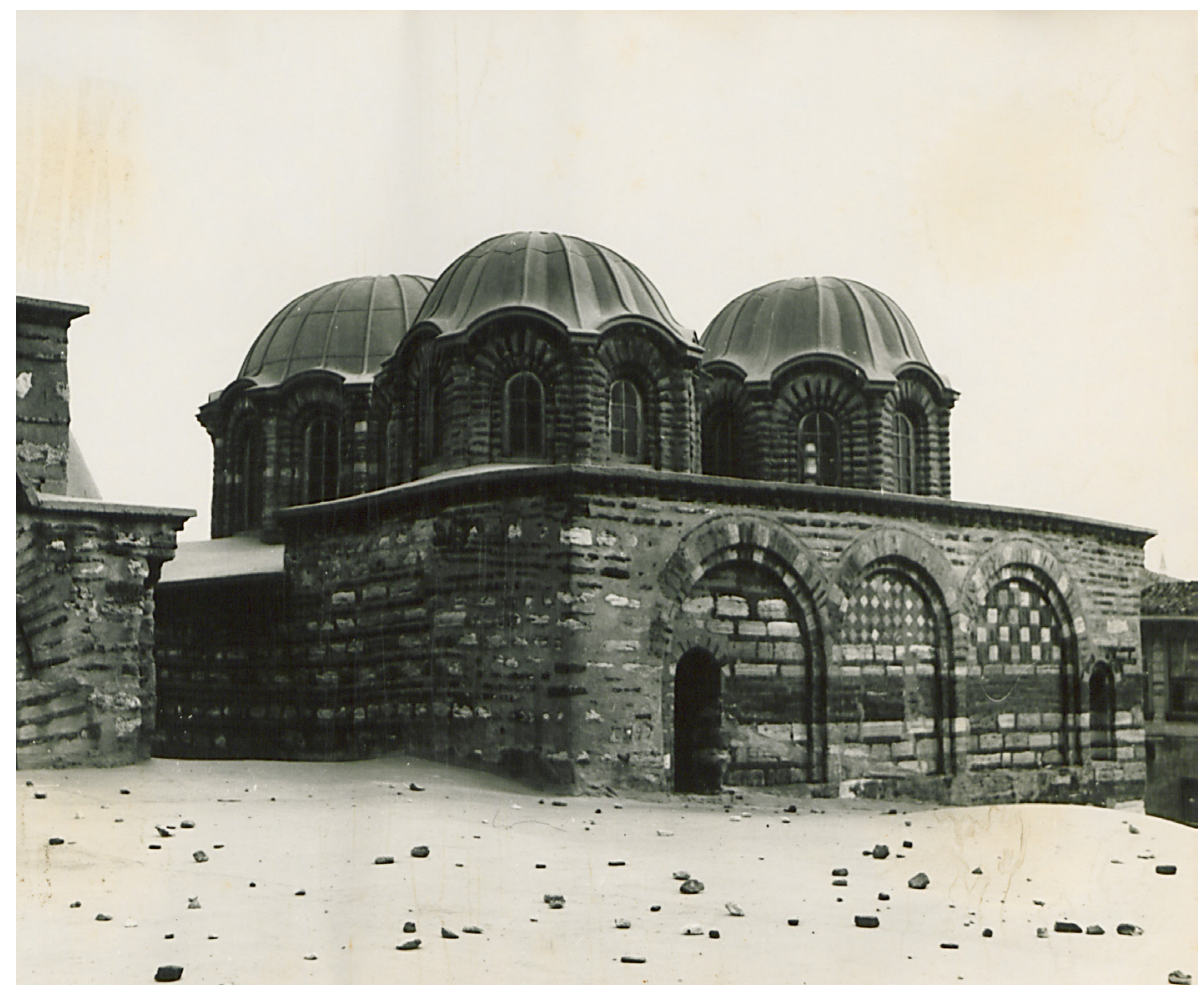


132
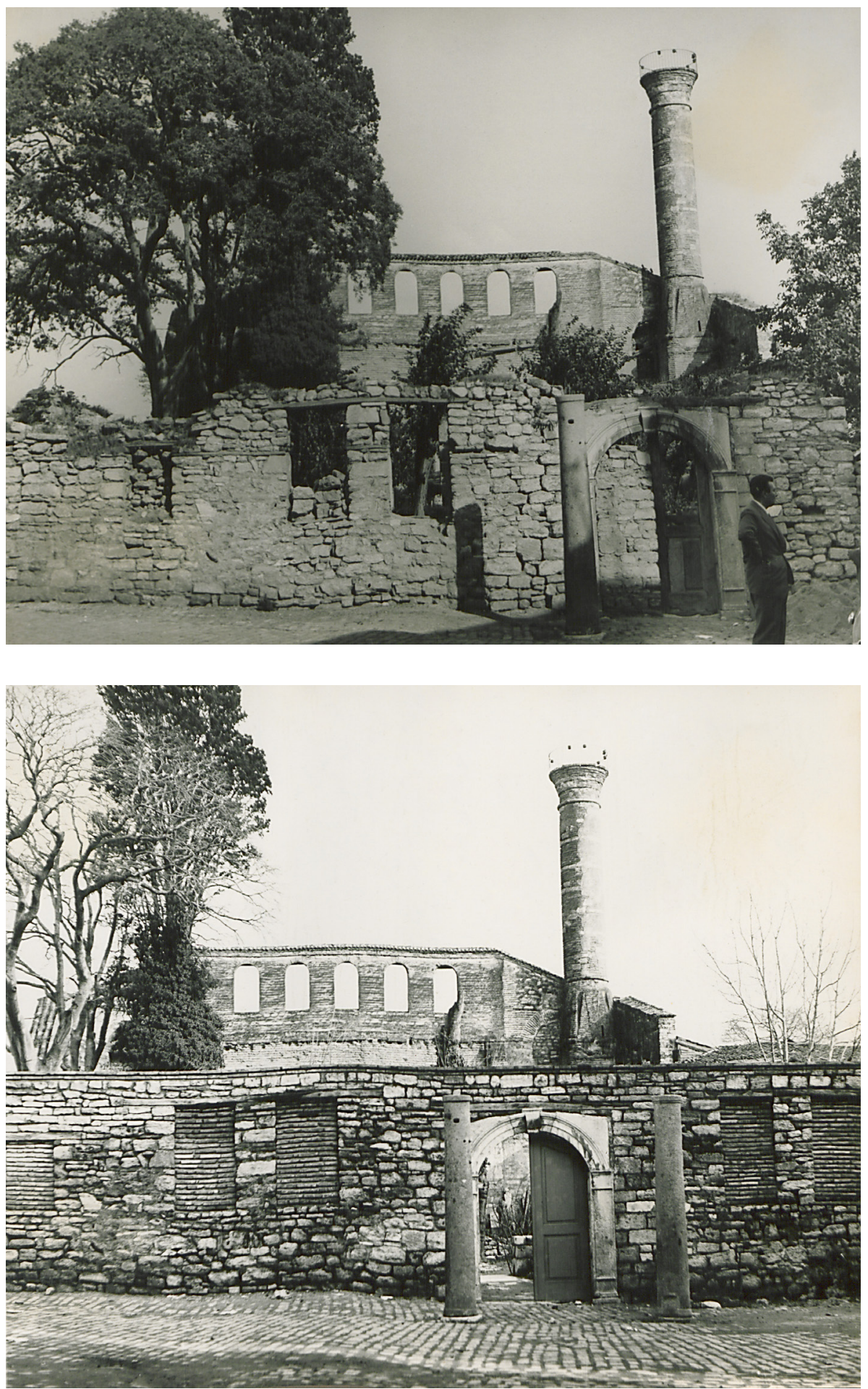

Figure 2a-2b: İmrahor Mosque, before and after. Cahide Tamer Collection, Koç University Suna Kıraç Library, CTA_S108_Ao1_ phg_22 and CTA_S108_ Ao1_phg_23. 
Figures 3a-3b: İmrahor Mosque, before and after. Cahide Tamer Collection, Koç University Suna Kıraç Library, CTA_S108_Ao1_ phg_24 and CTA_S108_ A01_phg_25.
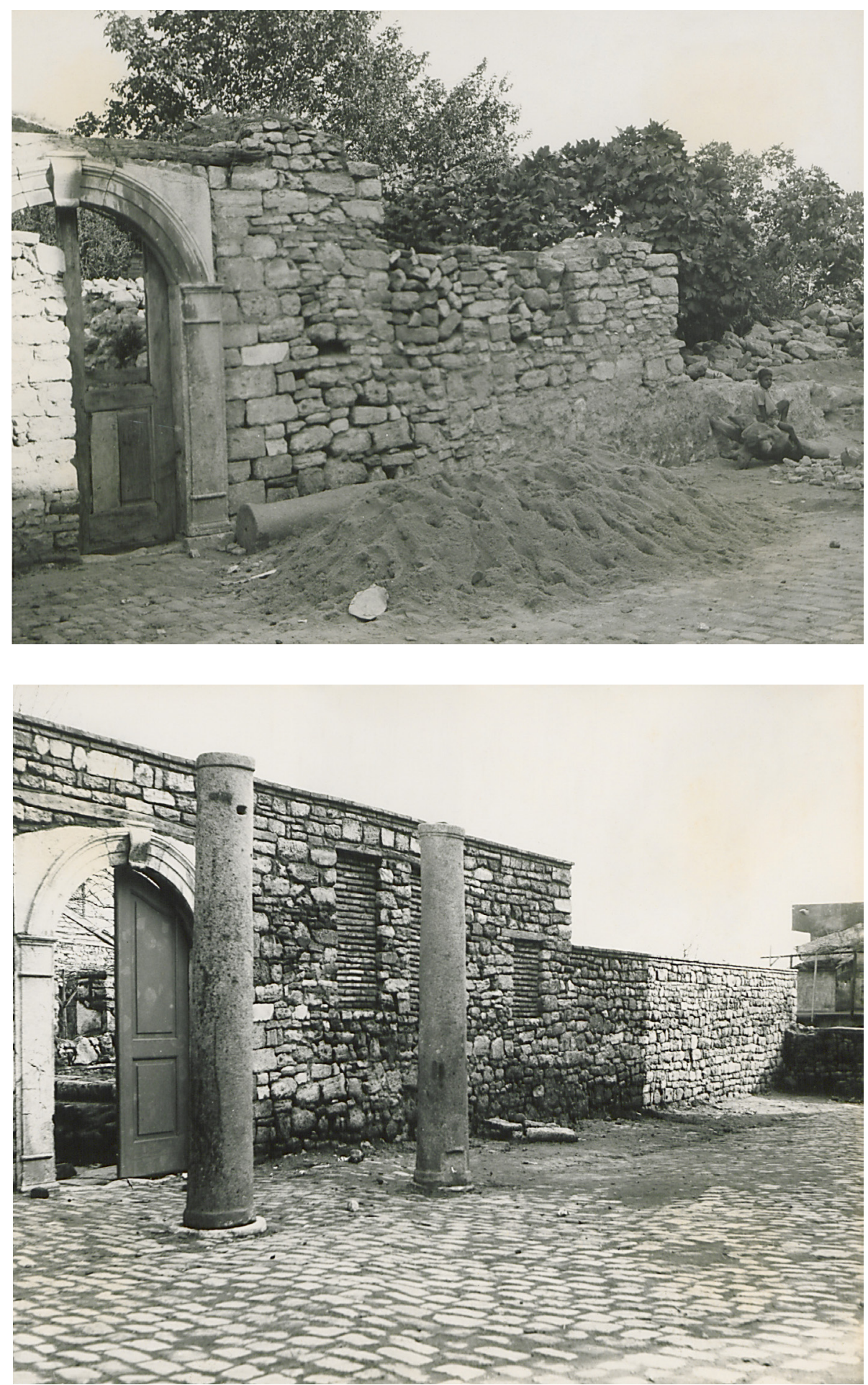
134
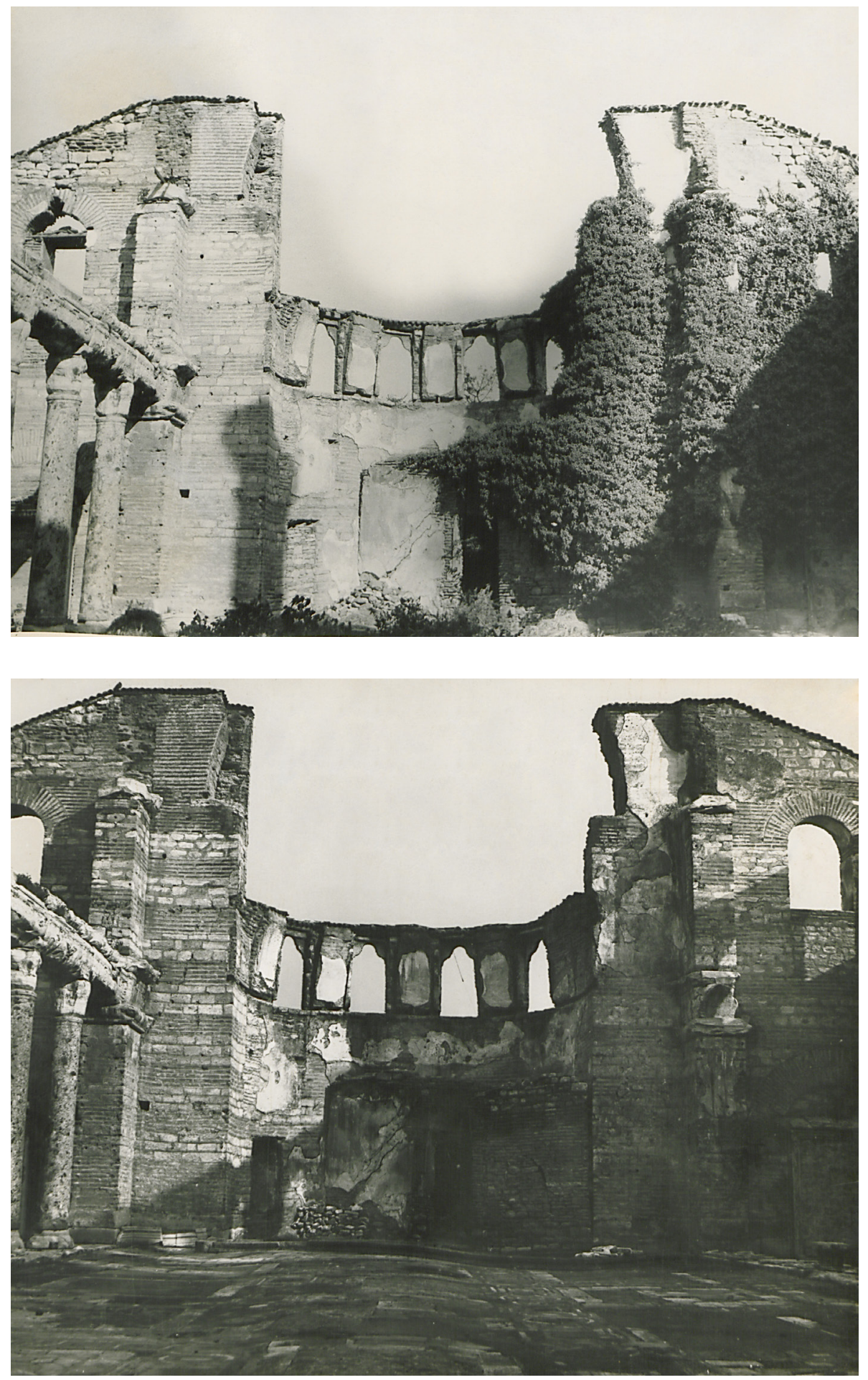

Figure 4a-4b: İmrahor Mosque, before and after. Cahide Tamer Collection, Koç University Suna Kıraç Library, CTA_S108_Ao1_ phg_28 and CTA_S108_ Ao1_phg_29. 

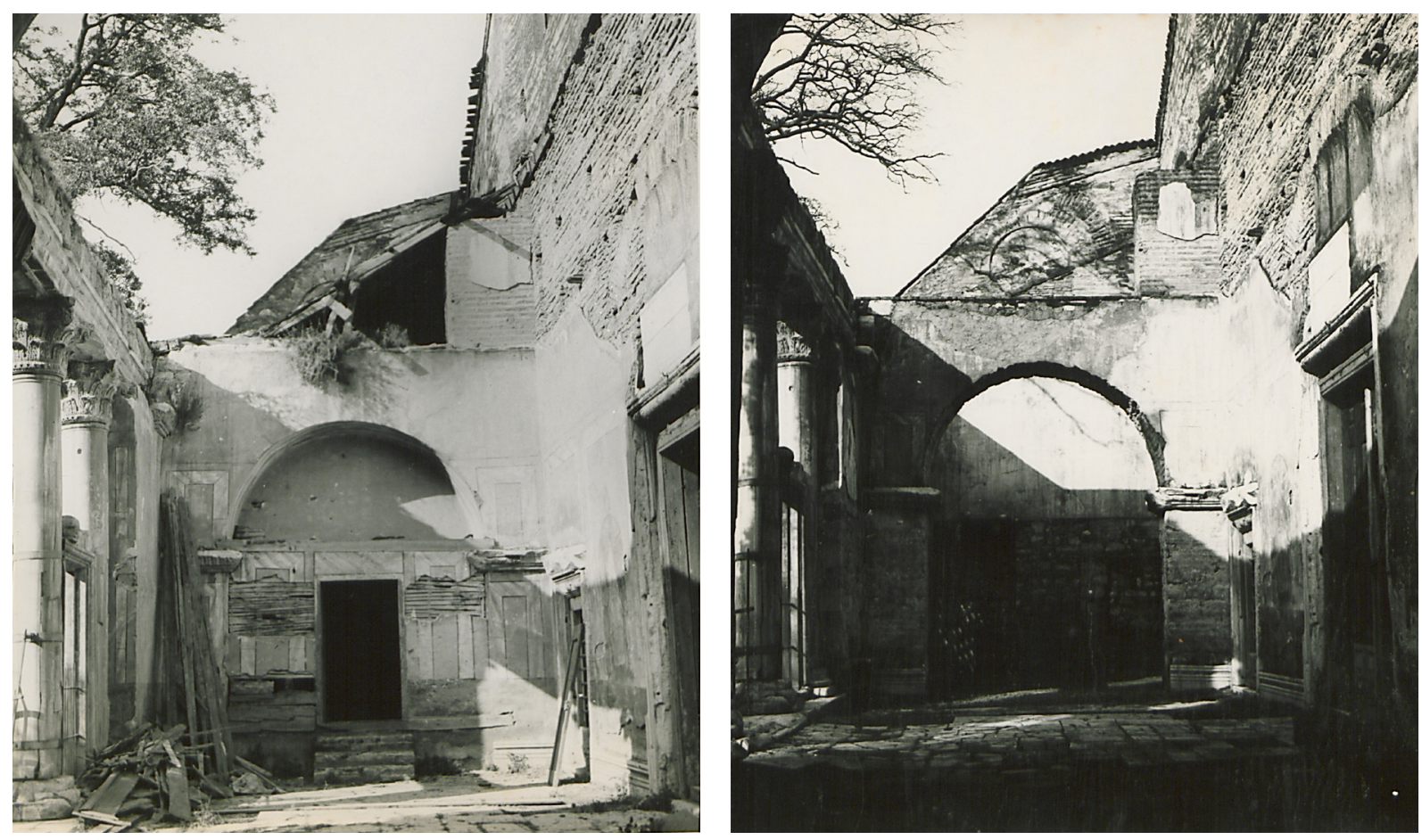

Figure 5a-5b: İmrahor Mosque, before and after. Cahide Tamer Collection, Koç University Suna Kıraç Library, CTA_S108_Ao1_phg_30 and CTA_S108_Ao1_phg_31. 
136
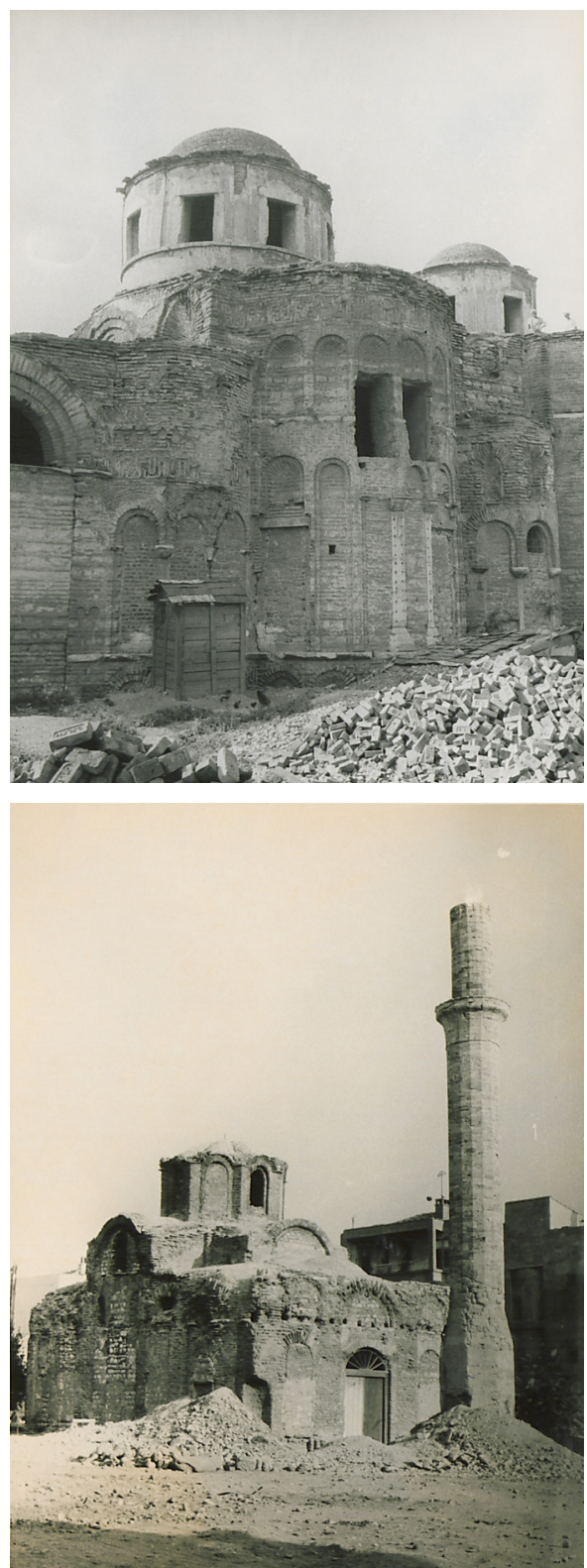
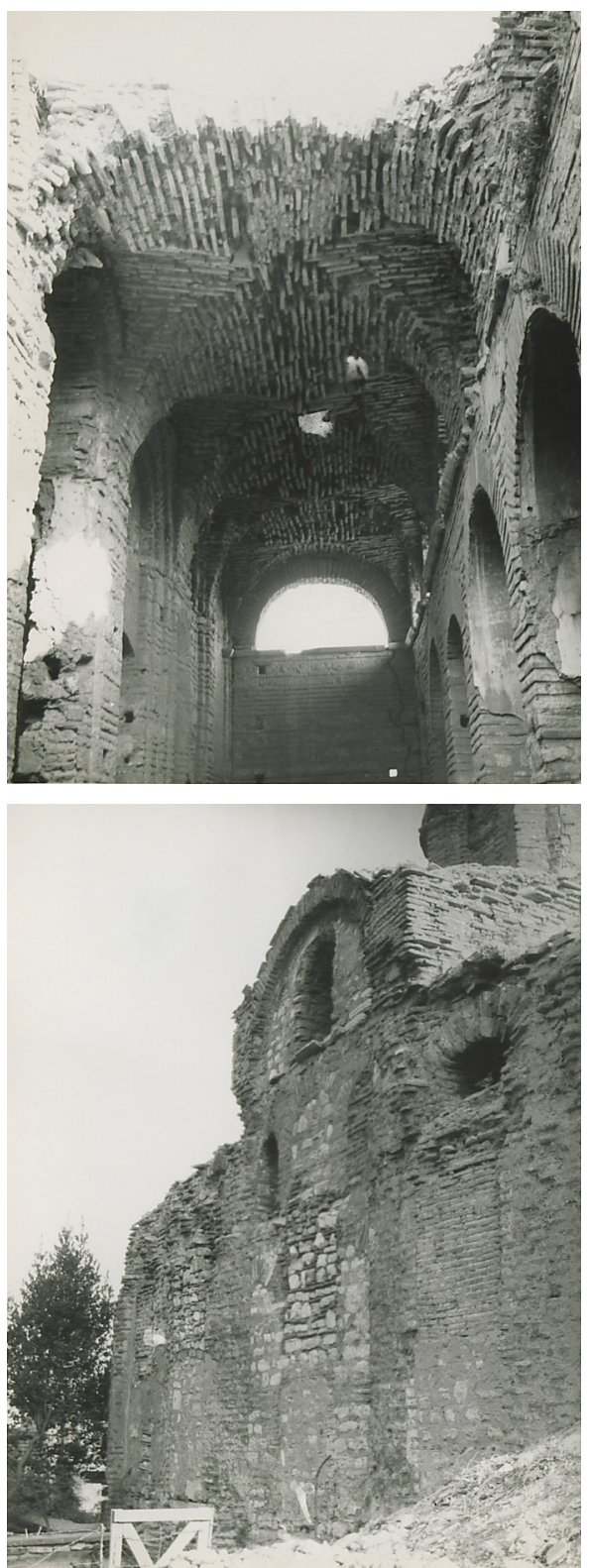

Figure 6-7: Fenari İsa Mosque. Cahide Tamer Collection, Koç University Suna Kıraç Library,

CTA_S108_Ao1_phg_34, CTA_S108_Ao1_phg_35.

Figure 8-9: Bodrum Mosque. Cahide Tamer Collection, Koç University Suna Kıraç Library, CTA_S108_Ao1_phg_36, CTA_S108_Ao1_phg_37. 

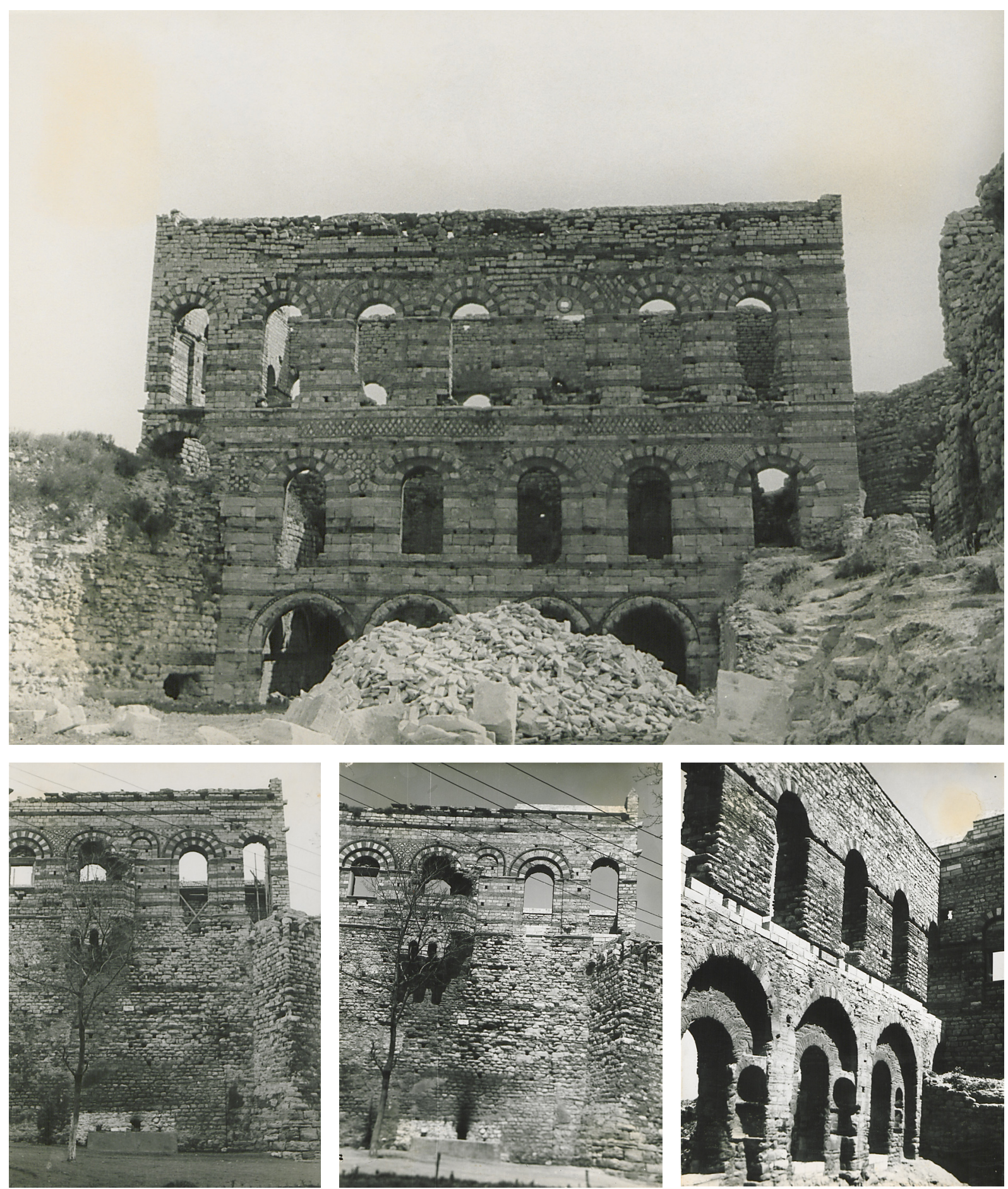

Figure 10-13: Tekfur Palace. Cahide Tamer Collection, Koç University Suna Kıraç Library, CTA_S108_Ao1_phg_38, CTA_S108_Ao1_phg_44, CTA_S108_Ao1_phg_45, CTA_S108_Ao1_phg_47. 
138
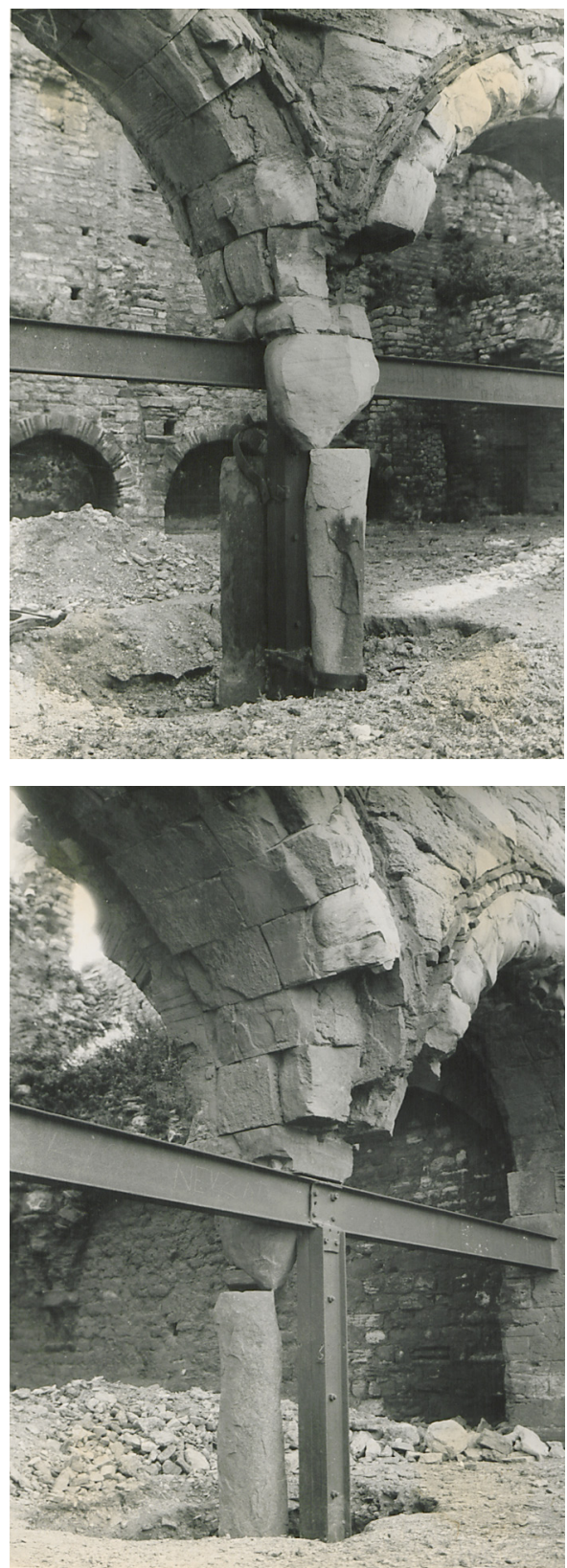
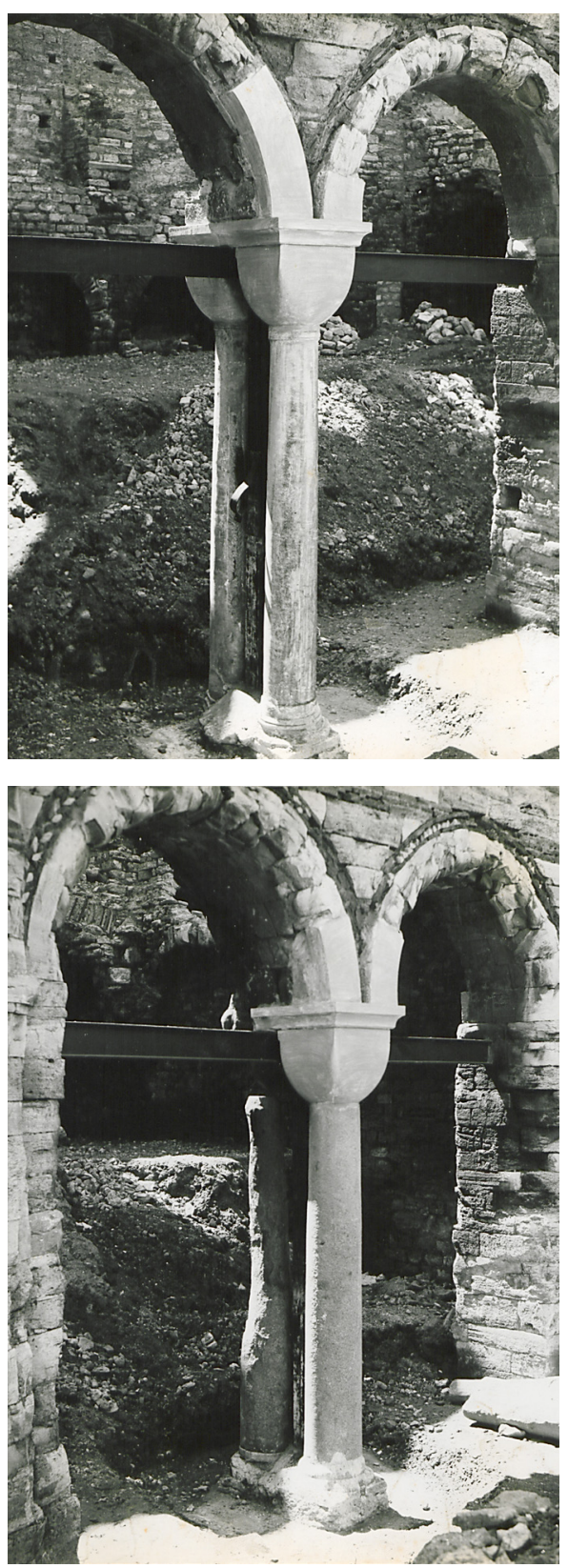

Figure 14-15:

Tekfur Palace.

Cahide Tamer Collection,

Koç University

Suna Kıraç Library,

CTA_S108_Ao1_phg_52

and CTA_S108_Ao1_

Figure 16-17:

Tekfur Palace.

Cahide Tamer Collection,

Koç University

Suna Kıraç Library,

CTA_S108_Ao1_phg_54

and CTA_S108_Ao1_ 
The 1oth International Congress of Byzantine Studies was inaugurated with the full support of the Turkish government under the auspices of Celal Bayar, the president of the Turkish Republic. The patronage committee included the prime minister of the Turkish Republic, the minister of foreign affairs, the minister of education, the governor of Istanbul, the president of Ankara University, the president of Istanbul University, the president of Istanbul Technical University, and the director of Antiquities and Museums. ${ }^{46}$

Although there were not many Byzantinists on the Turkish organizing committee, its members were the fruits of the politics of culture adopted during the early years of the Turkish Republic. The president of the organizing committee was Prof. Dr. Arif Müfid Mansel, who had served as the deputy director to Aziz Ogan, director of museums of Antiquities of Istanbul between 1930 and 1945. Mansel was the co-founder of the Department of Classical Studies and founder of the Institute for Archaeological Studies in the Antalya Region at Istanbul University. He was also the translator of Alexander Vasiliev's History of the Byzantine Empire into Turkish in 1943. Vice presidents were Ekrem Akurgal (professor of classical archaeology at Ankara University), Rüstem Duyuran (director of Istanbul Archaeological Museums), and Feridun Dirimtekin (director of Ayasofya Museum); the general secretary was Suat Sinanoğlu (professor of Greek philology at Ankara University); and the secretaries were Bahadır Alkım (associate professor of Hittitology at Istanbul University), Oktay Aslanapa (associate professor of Turkish and Islamic art at Istanbul University), Şerif Baştav (associate professor of Hungarology at Ankara University), and Semavi Eyice (associate professor of Byzantine art at Istanbul University).

The congress took place at Istanbul University in the building of the Faculty of Letters. Inauguration speeches were made on September 15, 1955 at the conference hall of Istanbul University by Celal Yardımc1, deputy minister of education; Prof. Dr. Fehim Firat, president of Istanbul University; and by Prof. Dr. Arif Müfit Mansel, president of the organizing committee. The inaugural address of the deputy minister of education was reminiscent of the way the Turkish Republic officially wished to present itself to the wider world. Celal Yardımc1 emphasized that the Turkish nation was the heir and protector of a one-thousand-year-old Byzantine civilization and its antiquities, and along with Turkish monuments and heritage, embraced them all as the cultural heritage of humanity. Istanbul's importance as the cradle of universal Byzantine and Turkish civilizations was pointed out. Yardımcı ended his speech by saying that the conversion of Ayasofya, a place of worship for the Turkish nation for five hundred years, into a museum, was a testimony of the Turkish nation's sincere commitment to preserve the cultural heritage of all civilizations. ${ }^{47}$

Twenty-one countries were officially represented at the Congress, with around 220 official delegates expected to be present. The largest official delegation was from Greece with fifty scholars. The Turkish delegation, comprised of twenty-eight scholars, four of whom were from the Patriarchal School of Halki (Rum Rahipler Okulu), followed the Greek delegation in number of participants. Then came the French delegation with twenty-five, Italian with twenty-two, and the German, French, and British delegations each with twenty scholars. The Russian delegation officially attended a congress of Byzantine studies for the first time in the history of these international congresses. Although the members of the Greek delegation were listed in the proceedings of the congress, the Greek delegation pulled out of the congress in protest of the events of September 6-7, 1955 as most of the people effected by the riots and plunder of these events were from the Rum community of Istanbul. The only Greek scholar present was P. loannu, an associate professor at the University of Munich, who participated in the congress as part of the German delegation.

The program, excursions, and exhibitions give the impression that the organizing committee and the government put a substantial effort into organizing an international congress on Byzantine studies comme il faut. As it had been the tradition since the third congress, the 
program was divided into five sections: philology, history, archaeology, history of art, and law. Among the 115 papers, fifteen were presented by scholars from Turkey. Five of these scholars-M. Tayyip Okiç, Robert Anhegger, Katharina Otto-Dorn, Aurel Decei, and Andreas Tietze-were long-time visiting professors teaching at Turkish universities..$^{48}$ The organizing committee published four books on the occasion of the congress: Istanbul, petit guide à travers les monuments byzantins et turcs by Semavi Eyice (Istanbul, 1955); Istanbul Arkeoloji Müzeleri Seçme Bizans Eserleri Rehberi by Nezih Firatlı (Istanbul, 1955); A Short Guide to the Byzantine Works of Art in the Archaeological Museum of Istanbul by Nezih Firatlı (Istanbul, 1955); and Informations pratiques pour les congressistes by Oktay Aslanapa (Istanbul, 1955).

There were two receptions: an opening reception given at Taksim Municipality Hall by Prof. Dr. Mehmed Fuad Köprülü, the deputy prime minister, ${ }^{49}$ and a closing reception held in the reception hall of Istanbul University by Prof. Dr. Fehim Firat and Prof. Dr. Arif Müfid Mansel. Five excursions were organized: to the Bosphorus and the Princes Islands on September 18; around the city of Istanbul on September 20; to central Anatolia (Ankara, Kayseri, and Göreme) between September 22 and 27; and to western Anatolia (Bursa, Izmir, and Efes) between September 22 and 27. Three exhibitions were held: the collection of recent acquisitions of Byzantine artifacts and jewelry at the Istanbul Archaeological Museums; exhibition of Byzantine manuscripts at Topkapı Palace; and a book exhibition at the Faculty of Letters of Istanbul University, by the Ministry of Education, the Turkish History Foundation, the Istanbul Institute, and the Touring Club of Turkey. ${ }^{50}$ In honor of the congress, a special series of postage stamps and envelopes were issued (fig. 18).

According to Raymond Janin, a large audience and especially students attended the congress. At the closure of the congress, Henri Grégoire, president of AIEB in 1955, expressed his wish that an institute of Byzantine studies would be founded in Istanbul..$^{51}$ Turkish newspapers announced the congress. Both Milliyet and Cumhuriyet newspapers informed their readers about its inauguration on their front pages on September 16, 1955 (fig. 19). Then on September 20, Milliyet on its third page gave details about the papers and events, and on September, 21,

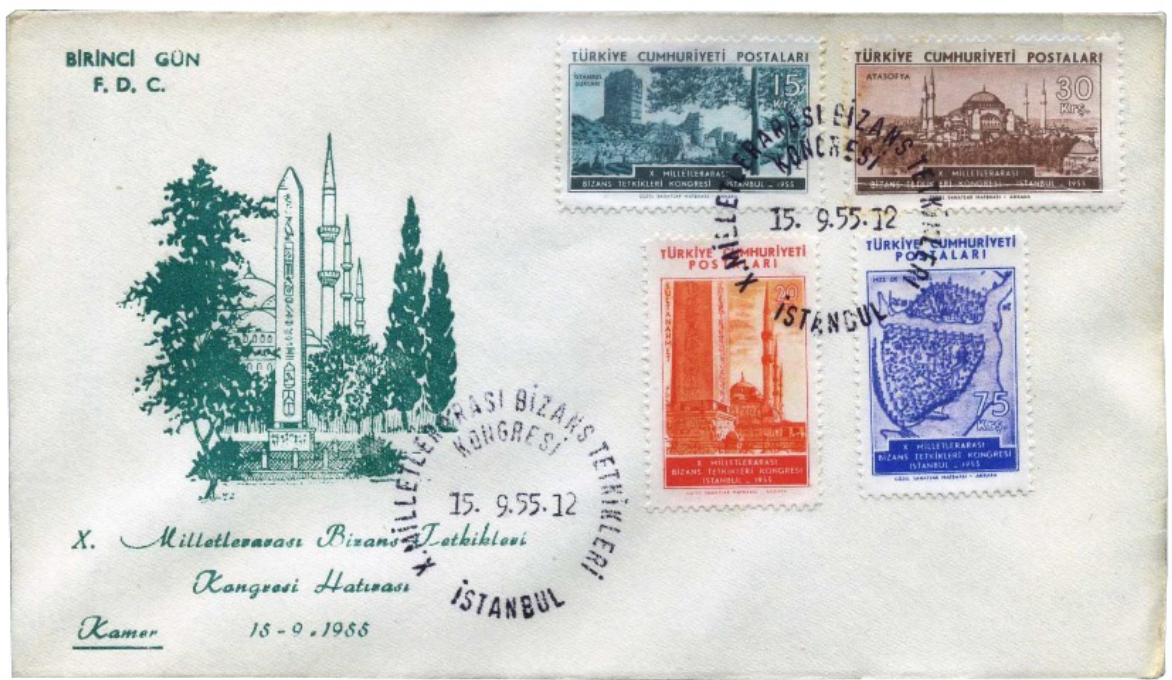

48 The papers presented by the Turkish delegation were as follows: Nezih Firatll, "The Bridge of Sangarius”; Mükerrem Usman Anabolu, "Some Interesting Byzantine Capitals"; P. Psalty, "Les ruines de la maison de la Vierge Marie à Panaya-Capouli"; Feridun Dirimtekin, "La forteresse byzantine de Selymbria"; Aurel Decei, "Les lieux de prière musulmans à Byzance avant la conquête turque"; Katharina OttoDorn, "Christliche elemente in der Omayyadischen Kunst;" Ekrem Hakkı Ayverdi, "Éléments architecturaux chez les Byzantins et Turcs"; Robert Anhegger, "Die Hagia Sophia und die osmanisch-türkische Moschee-architektur"; Zeki Velidi Togan, "Documents on Relations between the Ilhanides and Byzantines"; Halil İnalc1k, "An Ottoman Document on Bayezid l's Expedition in 1394 and the End of the Danubian Bulgary"; Serif Bastav, "Die Quellen der anonym türkischen Geschichte in griechischer Sprache"; M. Tayyib Okiç, "Les Kristians (Bogomiles) de Bosnie, d'après des documents turcs inédits"; Enver Esenkova, "Mots d'origine byzantine dans le roumain"; Andreas Tietze, "Griechische Lehnwörter im anatolischen Türkisch"; and Semavi Eyice, "La ville byzantine de Side en Pamphylie."

49 Mehmed Fuad Köprülü resigned from his position as minister of foreign affairs on April 15, 1955.

50 Actes $d u X$. congrès, 337, 339

51 Janin, "Le Xe congrès international d'études byzantines," 284. Henri Grégoire's wish would come true only after sixty years, in 2015, when two Byzantine studies centers were founded in Istanbul at Boğaziçi University and Koç University, respectively.
Figure 18: Envelope and postage stamps issued by the Turkish Post in honor of the 1oth International Congress of Byzantine Studies in Istanbul. Koleksiyon Adast, accessed November 19, 2019, http://koleksiyonodasi. com/15-eylul-1955-xmilletlerarasi-bizanstetkikleri-kongresi/. 
Figure 19: Front page of the Cumhuriyet Newspaper, September 16, 1955 . Cumhuriyet Archives.

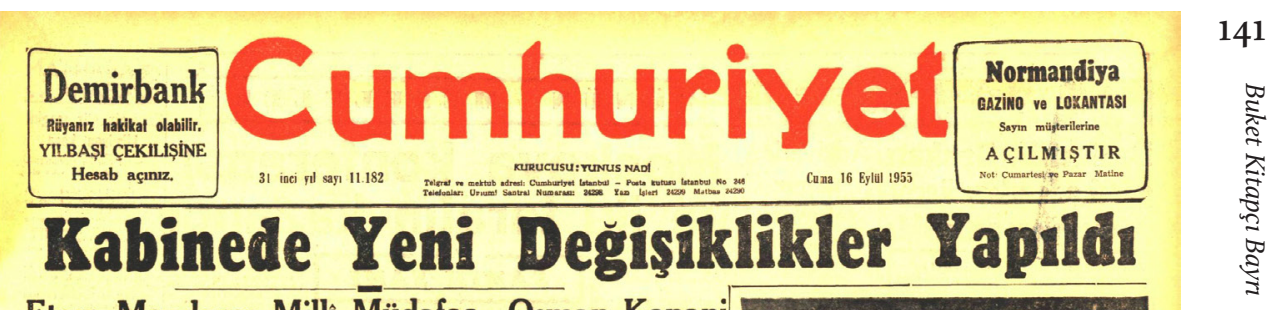

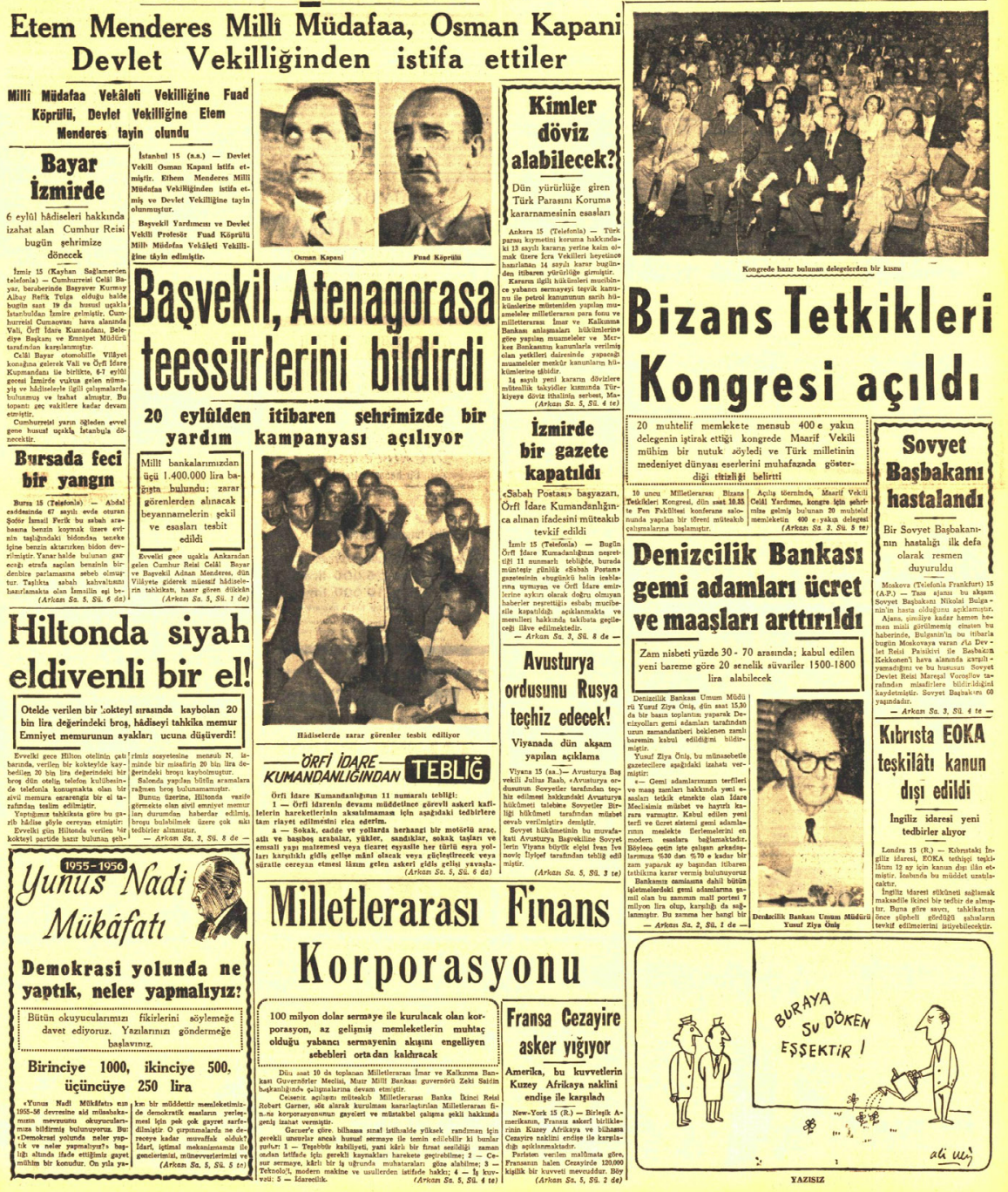

Cumhuriyet on its front page and on page five announced the closing of the congress. It should also be noted that there seemed to be a special interest in organizing international congresses in Turkey and especially in Istanbul during those years. In the same month of the same year, three other international congresses were held in Istanbul: the International Congress on Criminology, the UNESCO International Congress on Comparative Law, and the International Congress on Road Construction..$^{22}$ This appetite and ambition to hold international congresses deserve to be studied and addressed within the political, ideological, and economic contexts of the 1950 . 
The 1oth International Congress of Byzantine Studies was a result of the scientific and political developments that had taken place from the 1930s to the 1950s. Although the Byzantine heritage was problematic for the new Turkish nation, the creation of classical departments, translations, visits, and works and studies by both foreign and Turkish scholars had a significant impact on the development of Byzantine studies in Turkey. In the 1950s, the political and ideological inclination was towards the Ottoman past, but it did not radically change the perception of classical and Roman heritage. At the same time, the assertion of Istanbul as the symbol of cultural and ideological politics in the 1950 s led to the redevelopment of the city and preservation of historical monuments.

The congress generated discussions in the Grand National Assembly on the preservation and protection of small Byzantine archaeological finds such as lead seals and the restoration and maintenance of Byzantine monuments. It led to a campaign of restoration and repair of Byzantine historical monuments in Istanbul and all over Turkey. Although prior to the congress cleaning, repair, and maintenance of monuments were sometimes carried out on a small scale, the impetus of restoring Byzantine monuments continued well into the 1960 . Eight years after the congress, for the first time in Turkey, a department of Byzantine studies (a department of Byzantine art) was founded at Istanbul University. Participants of the congress, such as Raymond Janin, Henri Grégoire, and Romilly Jenkins, all praised the efforts of the organizing committee in their reviews, and yet as eyewitnesses of the aftermath of September 6-7, their writings convey their shock. In fact, it is unfortunate that the memories of the events of September 6-7 would remain over those of the 1oth International Congress of Byzantine Studies and its contributions to Byzantine studies in Turkey.

\section{Bibliography}

\section{Archival Sources}

Cahide Tamer Collection, Koç University Suna Kıraç Library.

TBMM Tutanakları, TBMM Kütüphane ve Arşiv Hizmetleri Başkanlığı.

\section{Published Sources}

Actes du X. congrès international d'études byzantines (Istanbul, 15-21. IX.1955). Istanbul: Publication du Comite d'Organisation du X. Congres International d'Etudes Byzantines, 1957.

Aktar, Ayhan. "6-7 Eylül 1955, Cumhuriyet Tarihinin En Karanlık Gecesi." Sabah Gazetesi, 5-6-8-9, September 2005. Accessed June 25, 2019. https://www.sosyalbilimler.org/ayhan-aktar-yazdi-6-7eylul-1955-cumhuriyet-tarihinin-en-karanlik-gecesi/.

Akyürek, Engin. "Modern Türkiye'de Bizans Sanatı Tarihi." Cumhuriyet Dönemi Geçmişe Bakış Açıları: Klasik ve Bizans Dönemleri, edited by Scott Redford and Nina Ergin, 241-262. Istanbul: Koç Üniversitesi Yayınları, 2010.

Altınyıldız, Nur. "The Architectural Heritage of Istanbul and the Ideology of Preservation." Muqarnas 24 (2007): 281-306.

Anastasijević, Dragutin N., and Philaret Granić, eds. Deuxième congrès international des études byzantines. Belgrade, 1927. Sous le haut patronage de Sa Majesté le Roi des Serbes, Croates et Slovènes. Compte-rendu. Nendeln: Kraus Reprint, 1978 [1929].

Auzépy, Marie-France, and Jean-Pierre Grélois. Byzance retrouvée: érudits et voyageurs français (XVle-XVIIle siècles), Chapelle de la Sorbonne, Paris 13 août-2 septembre 2001. Paris: Centre d'études byzantines, néohelléniques et sud-est européennes and Publications de la Sorbonne-Byzantina Sorbonensia, 2001.

Başarır, Başar. “30 Yıl Restorasyon: Cahide Tamer.” İstanbul 13 (1995): 94-98.

Baştav, Şerif. Ordo Portae: description grecque de la Porte et de l'armée du sultan Mehmed II. Budapest: Pázmány Péter Tudományegyetemi Görög Filológiai Intézet, 1947.

Delilbaşı, Melek. "The Classical Tradition, Byzantine and Modern Greek Studies in Turkey and Future Prospects." Association internationale d'études du Sud-Est Européen Revue 35-39 (2005-2009): 259-266.

Diehl, Charles. Bizans Imparatorluğu Tarihi. Translated by Cevdet R. Yularkıran. Istanbul: Kanaat Kitapevi, 1939.

— Diehl, Charles. Bizans Imparatorluğu Tarihi. Translated by Tevfik Bıyıklığlu. Istanbul: Vakit Matbaas1, 1937.

Eldem, Edhem. "Cultural Heritage in Turkey: An Eminently Political Matter." Essays on Tourism, Heritage and Society in the Mena Region. Proceedings of the International Heritage Confrence 2013 at Tangier, 
Morocco, edited by Dieter Haller, Achim Lichtenberger, and Meike Meerpohl, 67-91. Paderborn: Ferdinand Schöningh, 2015.

Eyice, Semavi. "Alfons Maria Schneider." TDV İslâm Ansiklopedisi, v. 6, 232-233. İstanbul: TDV İslam Araştırmaları Merkezi, 2009.

. "Ölümü Münasebetiyle: İstanbul Arkeoloji Müzeleri eski müdürü Aziz Ogan (1888-1956).” Türk Yurdu 263 (December 1956): 421-428.

- "Türkiye'de Bizans Mimarisi Hakkında Yabancı Araştırmaların Kısa Tarihçesi (ikinci Dünya Savaşına Kadar).” Sanat Tarihi Yıllı̆̆ı 6 (1976): 453-470.

—_. "Türkiye'de Bizans Sanatı Araştırmaları ve İstanbul Üniversitesi'nde Bizans Sanatı." Cumhuriyet'in 50. Yılına Armağan, 375-428. Istanbul: İstanbul Üniversitesi Edebiyat Fakültesi Matbaas1, 1973.

Filov, Bogdan D., ed. Actes du congrès international des études byzantines, Sofia, septembre 1934. 2 volumes. Sofia: Imprimerie de la Cour, 1935.

Fodac, Florina. "Le premier Congrès international des études byzantines (Bucarest, 14-20 avril 1924). Prémisses et context historique d'organisation." Études byzantines et post-byzantines 5 (2006): 509-522.

Graindor, Paul. "Le premier congrès des Études byzantines." Revue belge de philologie et d'histoire 3 (1924): $673-675$.

Grégoire, Henri. "Le IXe congrès des études byzantines Thessalonique, 12-25 avril 1953. Rapport préliminaire." Byzantion 22 (1952): 405-436.

—. "Le troisième congrès des études byzantines à Athènes (du 12 au 18 octobre 1930)." Byzantion 6, n. 1 (1931): 509-516.

- "Note provisioire sur le Xe congrès international d'études byzantines (Istanbul, 15-21 septembre 1955)." Byzantion 24, v. 1 (1954): 313-315.

—. "Notes et informations." Échos d'Orient 137 (January-March 1925): 56-67.

Grumel, Venance. "Le IXe Congrès international des études byzantines (Thessalonique 12-15 avril 1953)." Revue des études byzantines 12 (1954): 214-217.

Güven, Dilek. "Riots against the Non-Muslims of Turkey: 6/7 September 1955 in the Context of Demographic Engineering." European Journal of Turkish Studies. Social Sciences on Contemporary Turkey 12 (2011). Accessed November 22, 2019. https://journals.openedition.org/ejts/4538.

Iorga, Nicolae. Byzance après Byzance: Continuation de l'histoire de la vie byzantine. Bucarest: Institut d'études byzantines, 1935 .

Janin, Raymond. "Le Xe congrès international d'études byzantines (Istanbul, 15-21 septembre 1955)." Revue des études byzantines 13 (1955): 281-284.

Jeffreys, Elizabeth, John Haldon, and Robin Cormack, eds. The Oxford Handbook of Byzantine Studies. Oxford: Oxford University Press, 2008.

Jenkins, Romilly J.H. “Tenth International Congress of Byzantine Studies.” Archaeology 9, no. 1 (March 1956): 60-62.

Kioussopoulou, Tonia. "La délégation grecque au Ile Congrès international des études byzantines (Belgrade, 1927).” Héritages de Byzance en Europe du Sud-Est à l'époque moderne et contemporaine, edited by Olivier Delouis, Anne Couderc, and Petre Guran, 403-411. Athens: École française d'Athènes, 2013.

Kılıç Yıldız, Şule. "A Review of Byzantine Studies and Architectural History in Turkey Today." Middle Eastern Technical University Journal of the Faculty of Architecture 28, no. 2 (2011): 63-80.

Klein, H. A., R. G. Ousterhout, and B. Pitarakis, eds. Kariye. From Theodore Metochites to Thomas Whittemore: One Monument, Two Monumental Personalities. Istanbul: Pera Museum, 2010.

Koçu, Reşat Ekrem. Bizans Tarihi (Şarki Roma Imparatorluğu) 395-1453. Istanbul: Muallim Ahmet Halit Kitaphanesi, 1934

Koleksiyon Adast. Accessed November 19, 2019. http://koleksiyonodasi.com/15-eylul-1955-x-milletlerarasibizans-tetkikleri-kongresi/.

Köprülü, Mehmet Fuad. "Bizans Müesseselerinin Osmanlı Müesseselerine Tesiri Hakkında Bazı Mülahazalar." Türk Hukuk ve Iktisat Tarihi Mecmuast 1 (1931): 165-313.

Kurat, Akdes Nimet. Die türkische Prosopographie bei Laonikos Chalkokondyles. Hamburg: Neimann \& Moschinski, 1933.

Kurt, Selvihan Kurt. "Aziz Ogan ve Yabancı Bizantologların Yazışmaları Işı̆̆ında İstanbul'da Bizans Mirası Tartışmaları." Toplumsal Tarih 308 (2019): 62-69.

Marinescu, Constantin, ed. Compte-rendu du premier Congrès international des études byzantines, Bucarest 1924. Nendeln: Kraus Reprint, 1978 [1925].

Maufroy, Sandrine. "Les premiers congrès internationaux des études byzantines: entre nationalisme scientifique et construction internationale d'une discipline." Revue germanique internationale 12 (2010): 229-240.

Megaw, A.H. "Ninth International Congress of Byzantine Studies." Archaeology 6, no. 3 (September 1953): 181-183.

Necipoğlu, Nevra. "Türkiye’de Bizans Tarihçiliğinin Dünü, Bugünü ve Sorunları." Toplumsal Tarih 112 (2003): $72-77$.

Nystazopoulou-Pélékidou, Marie. "L’histoire des congrès internationaux des études byzantines - Première partie." Byzantina Symmeikta 18 (2008): 11-33.

Orlandos, Anastasios C., ed. Ille Congrès international des Études byzantines. Compte rendu, Athens 1930. Nendeln: Kraus Reprint, 1978 [1932]. 
144 Ramazanoğlu, Muzaffer. "Neue Forschungen zur Architektur-Geschichte der Irenen-Kirsche und des Komplexes der Sophien-Kirche.” Atti dello VIII Congresso Internazionale di Studi Bizantini: Palermo, 3-10 Aprile 1951, v. 2, 232-235. Roma: Associazione nazionale per gli studi bizantini, 1953.

Redford, Scott, and Nina Ergin. Perceptions of the Past in the Turkish Republic: Classical Periods. Leuven: Peeters, 2010.

Tagmat, Çağla. "Fetih Derneği ve İstanbul'un Fethi'nin 50o. Yılı." Tarih, Kültür ve Sanat Araştırmaları Dergisi 3, no. 4 (December 2014): 46-6o.

Talbot Rice, Tamara, and Elizabeth Talbot Rice. Tamara: Memoirs of St. Petersburg, Oxford and Byzantium. London: Murray, 1996.

Tamer, Cahide. İstanbul Bizans Anttları ve Onarımları. İstanbul: Türkiye Turing ve Otomobil Kurumu, 2003.

Tanyeri-Erdemir, Tuğba. "Archaeology as a Source of National Pride in the Early Years of the Turkish Republic." Journal of Field Archaeology 31, no. 4 (2006): 381-393.

Vasiliev, Alexander A. Bizans Imparatorluğu Tarihi. Cilt 1. Translated by Arif Müfid Mansel. Ankara: Maarif Vekaleti, 1943.

Vogt, Albert. "Ille congrès international des études byzantines. Athènes 12-18 octobre 1930." Revue des questions historiques 51 (1931): 231-237. 